\title{
Um dia de fome em Cristiânia: Tradução das primeiras páginas do romance Sult, de Knut Hamsun
}

\author{
Ludmila Menezes Zwick' \\ Renato Zwick ${ }^{2}$
}

Resumo: Tencionamos, em primeiro lugar, problematizar de modo breve as interferências que as escolhas estilísticas e/ou lexicais do tradutor podem ter sobre a linguagem do autor traduzido, tomando como úni co exemplo alguns trechos de Fome, de Knut Hamsun, na tradução de Carlos Drummond de Andrade. Tais interferências, neste caso, são amplificadas de modo especial pelo fato de não se tratar de uma versão feita diretamente do idioma do autor, mas a partir do francês. Outrossim, visamos apresentar, como contraponto, uma tradução direta que abrange o trecho inicial do livro e, no tempo da narrativa, corresponde ao primeiro dia vivido pelo protagonista em suas andanças por Cristiânia, a atual Oslo.

Palavras-chave: literatura escandinava; Knut Hamsun; tradução dano-norueguês-português brasileiro; tradução direta versus tradução indireta.

1 É mestra em Estética e História da Arte pela USP e doutora em Letras (Literatura e Cultura Russa) pela mesma universidade. Pesquisa história da arte do século XIX e início do XX. No que concerne à literatura escandinava, seu primeiro contato foi com o norueguês Knut Hamsun, e, mais tarde, com o dinamarquês Jens Peter Jacobsen.

2 É bacharel em Filosofia pela Universidade Regional do Noroeste do Estado do Rio Grande do Sul (Unijuí) e mestre em Letras (Língua e Literatura Alemã) pela USP. É tradutor do alemão desde 2006, tendo vertido obras de Sigmund Freud, Friedrich Nietzsche (publicadas pela editora L\&PM) e Karl Kraus (Arquipélago Editorial), entre outros. Dentre os autores nórdicos, tem especial interesse por Jens Peter Jacobsen e Knut Hamsun. 


\section{Knut Hamsun, breve apresentação}

Lido, citado e admirado por escritores tão diversos quanto Thomas Mann, Franz Kafka e Henry Miller, Knut Hamsun (1859-1952) é autor de vasta obra que abrange artigos, romances, peças de teatro e poesia.

Como Knut Pedersen, seu nome de batismo, publicou apenas dois títulos: Den Gaadefulde (O enigmático, 1877) e Bjorger (Cidadãos, 1878). Os romances seguintes já seriam publicados sob o nome que o tornou conhecido: Sult (Fome, 1890), Mysterier (Mistérios, 1892), Ny Jord (Terra nova, 1893), Redaktor Lynge (O redator Lynge, 1893), Pan (Pã, 1894), Victoria (1898), Svarmere (Os sonhadores, 1904), Under Hoststjarnen (Sob a estrela outonal, 1906), Rosa, Benoni (ambos de 1908), En Vandrer spiller med Sordin (Um andarilho toca em surdina, 1909), Den sidste Glade (A última alegria, 1912), Born af Tiden (Filhos da época, 1913), Segelfoss By (A cidade de Segelfoss, 1915), Markens Grode (Os frutos da terra, 1917), Konerne ved Vandposten (As mulheres da bomba d'água, 1920), Sidste Kapitel (Último capítulo, 1923), Landstrykere (Vagabundos, 1927), August (1930), Men Livet lever (E a vida continua, 1933) e Ringen sluttet (O círculo fechado, 1936).

No gênero novela, publicou Siesta (1897) e Stridende Liv (Vida de lutas, 1905); suas peças de teatro foram: Ved Rigets Port (Às portas do reino, 1895), Livets Spil (O jogo da vida, 1896), Aftenrode (Arrebol, 1898), Dronning Tamara (A rainha Tamara, 1903), Munken Vendt (O monge Vendt, 1904) e Livet $i$ Vold (À mercê da vida, 1910).

Além disso, entre outras obras, ainda publicou um volume de conferências (Fra de moderne Amerikas Aandsliv [Da vida intelectual na América moderna], 1889), um de relatos de viagem (I ÆEventyrland [No país fabuloso], 1903) e outro de poesias (Det vilde Kor [O coro selvagem], 1904).

Em 1940, a Noruega foi invadida pelos nazistas, e Hamsun, numa infeliz mostra de miopia política, manifestou simpatia por Hitler, decepcionando muitos de seus leitores. Era, porém, avesso à violência e jamais aderiu ao antissemitismo. Já sozinho, morando num asilo, após ter vivido uma vida relativamente plena, em especial após seu casamento com a atriz e autora de livros infantojuvenis Marie Andersen, em 1909, Hamsun compôs sua última obra, Paa gjengrode Stier (Por veredas cobertas de relva, 1949).

\section{Sult, uma tradução indireta}

Romance autobiográfico publicado em 1890, trinta anos antes de seu autor receber o prêmio Nobel pelo romance Markens Grode (Os frutos da terra), Sult 
(Fome) teve duas traduções brasileiras: a de Adelina Fernandes (1934) e a de Carlos Drummond de Andrade (1971). Esta última - que, como para tantos outros leitores, também representou nosso primeiro contato com esse autor - foi publicada como volume integrante da coleção "Biblioteca dos prêmios Nobel de literatura", equivalente brasileira da "Collection des prix Nobel de littérature", no âmbito da qual se reeditou em 1969 a tradução de Georges Sartreau (La faim, 1926). Na edição brasileira, ainda que se informe à página 6 que o "título do original norueguês" é Sult, não se informa ao leitor que o texto-fonte efetivo é muito provavelmente o da tradução francesa de Georges Sartreau.

A escolha por realizar uma tradução indireta, malgrado a inequívoca perícia de Drummond com a língua portuguesa, levou a muitas desfigurações lexicais e estilísticas do texto hamsuniano, conforme o quadro abaixo mostra sucintamente com alguns exemplos:

\begin{tabular}{|c|c|c|c|}
\hline Hamsun & Sartreau & Drummond & Nossa tradução \\
\hline (1) sulted (p. 1) & la faim au ventre (p. 67) & $\begin{array}{l}\text { com a barriga na } \\
\text { miséria (p. 63) }\end{array}$ & passava fome \\
\hline (2) nedenunder mig (p. 1) & au-dessous de moi (p. 67) & lá embaixo (p. 63) & abaixo de mim \\
\hline $\begin{array}{l}\text { (3) fedt, bugnende Aver- } \\
\text { tissement (p. 1) }\end{array}$ & $\begin{array}{l}\text { grasse et rebondie, une } \\
\text { annonce (p. 67) }\end{array}$ & $\begin{array}{l}\text { vasto, rechochudo, o } \\
\text { anúncio (p. 63) }\end{array}$ & $\begin{array}{l}\text { um anúncio gordo e } \\
\text { inchado }\end{array}$ \\
\hline (4) Ejendele (p. 1) & effets (p. 67) & roupas (p. 63) & pertences \\
\hline (5) af Svimmelhed (p. 2) & $\begin{array}{l}\text { à cause de vertiges ( } p . \\
67)\end{array}$ & $\begin{array}{l}\text { em estado vertiginoso } \\
\text { (p. 63) }\end{array}$ & por causa de tonturas \\
\hline $\begin{array}{l}\text { (6) magre, grinende Bogs- } \\
\text { taver (p. 2) }\end{array}$ & $\begin{array}{l}\text { maigres caractères grima- } \\
\text { çants (p. 68) }\end{array}$ & $\begin{array}{l}\text { as letras finas e tortas } \\
\text { (p. 63) }\end{array}$ & $\begin{array}{l}\text { as letras magras e } \\
\text { arreganhadas }\end{array}$ \\
\hline $\begin{array}{l}\text { (7) alting skifter Farve og } \\
\text { forgaar (p. 2) }\end{array}$ & $\begin{array}{l}\text { toutes choses changent } \\
\text { de couleur et passent de } \\
\text { vie à trépas (p. 68) }\end{array}$ & $\begin{array}{l}\text { as folhas mudam de } \\
\text { cor e passam desta } \\
\text { para melhor (p. 64) }\end{array}$ & $\begin{array}{l}\text { tudo muda de cor e } \\
\text { perece }\end{array}$ \\
\hline $\begin{array}{l}\text { (8) dette tomme Værelse } \\
\text { (p. 2) }\end{array}$ & cette chambre vide (p. 68) & $\begin{array}{l}\text { aquele quarto lúgubre } \\
\text { (p. 64) }\end{array}$ & esse quarto vazio \\
\hline $\begin{array}{l}\text { (9) jeg gik videre gennen } \\
\text { Gaderne (p. 7) }\end{array}$ & $\begin{array}{l}\text { je continuai à marcher } \\
\text { par les rues (p. 70) }\end{array}$ & $\begin{array}{l}\text { continuei a rodar por } \\
\text { aí (p. 66) }\end{array}$ & $\begin{array}{l}\text { segui em frente pelas } \\
\text { ruas }\end{array}$ \\
\hline $\begin{array}{l}\text { (10) Jeg havde slet ikke i } \\
\text { Sinde at bede ham om en } \\
\text { Krone (p. 8) }\end{array}$ & $\begin{array}{l}\text { Je n'avais pas la moindre } \\
\text { intention de lui demander } \\
\text { une couronne (p. } 70 \text { ) }\end{array}$ & $\begin{array}{l}\text { Eu não tinha a menor } \\
\text { intenção de pedir-lhe } \\
\text { qualquer coisa (p. 66) }\end{array}$ & $\begin{array}{l}\text { Eu não tinha em } \\
\text { mente de forma } \\
\text { alguma pedir-lhe uma } \\
\text { coroa }\end{array}$ \\
\hline $\begin{array}{l}\text { (11) og øse af min fulde } \\
\text { Hjærne (p. 8) }\end{array}$ & $\begin{array}{l}\text { pour épancher la ple- } \\
\text { nitude de mon cerveau } \\
\text { (p. } 70)\end{array}$ & $\begin{array}{l}\text { para expandir a pleni- } \\
\text { tude das idéias (p. 67) }\end{array}$ & $\begin{array}{l}\text { e esvaziar meu cére- } \\
\text { bro cheio }\end{array}$ \\
\hline (12) masede Væsen (p. 9) & être obsédant (p. 71) & tipo obsessor (p. 67) & ser esmagado \\
\hline
\end{tabular}


No exemplo (1), não há dúvida de que as expressões escolhidas por Sartreau e Drummond são boas quando consideradas em si mesmas; porém, como traduções de um prosaico sulted, "passava fome", parecem pouco adequadas, pois convertem um termo neutro numa expressão quase poética - no caso do francês - e numa expressão coloquial - no caso do português.

No exemplo (2), a correta escolha do tradutor francês ganhou, em português, uma ênfase extra pelo acréscimo do "lá": o relógio que o protagonista ouve bater seis horas não está mais abaixo dele (mais precisamente, no andar imediatamente abaixo), mas bem mais distante (talvez no térreo?).

Em (3), o adjetivo "vasto" da versão brasileira tem uma conotação a um só tempo mais eufemística e mais ampla do que o mero adjetivo "gordo" (fedt em dano-norueguês, gras em francês).

Já em (4), os bens, posses ou pertences (Ejendele) do personagem são reduzidos na versão brasileira apenas às suas roupas, possivelmente devido a uma confusão causada pela polissemia do termo francês, já que effets, além do plural de "efeito", também pode significar "bens" e "roupas íntimas". Ou seja, ainda que esta seja uma categoria específica de roupa, Drummond a ampliou.

No quinto exemplo, o simples enunciado de uma causa (af Svimmelhed - à cause de vertiges - por causa de tonturas) transforma-se na versão de Drummond em algo rebuscado e até enigmático: "em estado vertiginoso", o que interfere no estilo direto do autor.

Em (6), a opção do tradutor francês para o adjetivo grinende é adequada (grimaçant: que faz caretas ou esgares), o que não é o caso da de Drummond.

Em (7), Sartreau e, em sua esteira, Drummond optaram por um coloquialismo desbragado para traduzir o verbo forgaa, "perecer, fenecer". No caso de Drummond, ainda há o agravante de um amplíssimo alting (toutes choses - tudo) que, podemos imaginar, abrangeria não só plantas, mas inclusive outros objetos e mesmo estados de espírito - ser reduzido às meras e concretas folhas.

Em (8), um simples quarto vazio (tomme V crelse $=$ chambre vide) adquire na versão de Drummond um caráter bem mais sombrio.

No exemplo (9), a escolha de Drummond soa mais uma vez bastante coloquial.

Em (10), um objeto bem específico $($ en Krone $=$ une couronne = uma coroa $)$ converte-se em algo inespecífico na versão brasileira.

Em (11), uma expressão de caráter concreto, que ainda se conserva em francês, converte-se na versão de Drummond em algo sublime, pois um carnal 
"cérebro" (Hjorne = cerveau) transforma-se em imateriais "ideias". Note-se também a contradição entre "esvaziar" e "expandir": o protagonista quer colocar suas ideias logo no papel, pois já alcançaram uma boa expansão em seu cérebro, e não as expandir ainda mais.

Em (12), ao se referir a alguém que vê na rua, o protagonista o qualifica de "ser esmagado/criatura esmagada" (masede Vesen); não está claro porque Sartreau optou por "être obsédant", no que é seguido de perto por Drummond com "tipo obsessor".

Não há dúvida de que as traduções indiretas podem contribuir imensamente para a difusão de determinado autor que, de outro modo, talvez jamais tivesse leitores em certos idiomas não houvessem editores e tradutores recorrido a esse expediente. Por outro lado, também é certo que a existência de estações intermediárias na passagem de um texto a outro idioma aumenta a possibilidade da ocorrência de distorções na prosa de um autor, enquanto uma tradução direta, ainda que sujeita a males parecidos, é potencialmente menos suscetível de incorrer em tais distorções. 


\section{Sult, uma tradução direta}

Knut Hamsun

Tradução do norueguês:

Ludmila Menezes Zwick

Renato Zwick

O trecho ora traduzido corresponde às páginas 1-47 da primeira edição de Sult (København: P. G. Philipsen³ ${ }^{3}$ 1890). Os números de página vão indicados entre colchetes.

\section{Sult}

[1] Det var i den Tid, jeg gik omkring og sulted i Kristiania, denne forunderlige By, som ingen forlader, før han har faeet Mærker af den.....................

Jeg ligger vaagen paa min Kvist og hører en Klokke nedenunder mig slaa seks Slag; det var allerede ganske lyst, og Folk begyndte at færdes op og ned i Trapperne. Nede ved Døren, hvor mit Rum var tapetseret med gamle Numre af "Morgenbladet«, kunde jeg saa tydelig se en Bekendtgørelse fra Fyrdirektøren, og lidt tilvenstre derfra et fedt, bugnende Avertissement fra Bager Fabian Olsen om nybagt Brød.

Straks jeg slog Øjnene op, begyndte jeg af gammel Vane at tænke efter, om jeg havde noget at glæde mig til idag. Det havde været lidt knapt for mig $\mathrm{i}$ den sidste Tid; den

\section{Fome}

[1] Foi no tempo em que eu perambulava e passava fome em Cristiânia, essa cidade estranha que ninguém deixa antes de receber dela suas marcas...

Eu estava deitado em minha mansarda, acordado, e ouvi um relógio bater seis horas abaixo de mim; já estava bastante claro e as pessoas começavam a circular para cima e para baixo pelas escadas. Embaixo, junto à porta, onde meu quarto estava forrado com velhas edições do Morgenbladet, eu podia ver bem claramente um comunicado do diretor dos faróis e, um pouco à esquerda, um anúncio gordo e inchado do padeiro Fabian Olsen oferecendo pão fresco.

Logo que abri os olhos, comecei a refletir, como de costume, sobre se tive algo com que me alegrar até hoje. As coisas tinham sido um tanto escassas para mim nos úl-

3 A atual detentora dos direitos de publicação da obra de Hamsun é a editora Gyldendal. Os autores agradecem a Pasi Loman, da agência Vikings of Brazil, por intermediar gentilmente a obtenção da autorização para publicar este trecho. 
ene efter den anden af mine Ejendele var bragt [2] til »Onkel«, jeg var bleven nervøs og utaalsom, et Par Gange havde jeg ogsaa ligget tilsengs en Dags Tid af Svimmelhed. Nu og da, naar Lykken var god, kunde jeg drive det til at faa fem Kroner af et eller andet Blad for en Føljeton.

Det lysned mer og mer, og jeg gav mig til at læsepaa Avertissementerne nede ved Døren; jeg kunde endog skælne de magre, grinendeBogstaver om »Ligsvøb hos Jomfru Andersen, tilhøjre i Porten«. Det sysselsatte mig en lang Stund, jeg hørte Klokken slaa otte nedenunder, inden jeg stod op og klædte mig paa.

Jeg aabned Vinduet og saa ud. Der, hvor jeg stod, havde jeg Udsigt til en Klædesnor og en aaben Mark; langt ude laa Gruen tilbage af en nedbrændt Smedje, hvor nogle Arbejdere var i Færd med at rydde op. Jeg ladge mig med Albuerne ned $\mathrm{i}$ Vinduet og stirred ud i Luften. Det blev ganske vist en lys Dag, Høsten var kommet, den fine, svale Aarstid, hvori alting skifter Farve og forgaar. Støjen var allerede begyndt at lyde i Gaderne og lokked mig ud; dette tomme Værelse, hvis Gulv gynged op og ned for hvert Skridt jeg [3] tog henover det, var som en gisten, uhyggelig Ligkiste; der var ingen ordentlig Laas for Døren og ingen Ovn i Rummet; jeg plejed at ligge paa mine Strømper om Natten, forat faa dem lidt tørre til om Morgenen. Det eneste, jeg havde at fornøje mig ved, var en liden rød Gyngestol, som jeg sad i om Aftenerne og døsed og tænkte paa mangehaande Ting. Naar det blæste haardt, og Dørene nedenunder stod aabne, lød der alleslags underlige Hvin op gennem Gulvet og ind fra Væggene, og »Morgenbladet« nede ved Døren fik Revner saa lange som en Haand. timos tempos; um a um, meus pertences foram colocados [2] no "prego", tornei-me nervoso e impaciente, e algumas vezes também passei o dia inteiro deitado na cama por causa de tonturas. Vez por outra, quando tinha sorte, conseguia ganhar cinco coroas neste ou naquele jornal por um folhetim.

Ficava cada vez mais claro e comecei a estudar os anúncios que estavam embaixo, junto à porta; podia ver inclusive as letras magras e arreganhadas de "mortalhas com a senhorita Andersen, à direita dos portões". Isso me ocupou por um bom tempo; ouvi o relógio embaixo bater oito horas antes que me levantasse e me vestisse.

Abri a janela e olhei para fora. De onde estava, via um varal e um campo aberto; lá fora, ao longe, uma fornalha foi o que ficou para trás de uma ferraria queimada até os alicerces, onde alguns trabalhadores estavam colocando tudo em ordem. Apoiei os cotovelos na janela e fiquei olhando para o nada. Seria sem dúvida um dia luminoso; chegara o outono, a estação amena e fresca em que tudo muda de cor e perece. O barulho já tinha começado a ressoar nas ruas e me atraía para fora; esse quarto vazio, cujo assoalho balançava para cima e para baixo a cada passo que eu [3] dava sobre ele, era como um caixão rachado e medonho; não havia propriamente fechadura na porta e nem estufa no quarto; eu costumava me deitar sobre minhas meias durante a noite para conseguir secá-las um pouco até de manhã. A única coisa que eu tinha para me alegrar era uma pequena cadeira de balanço vermelha, em que me sentava durante as noites e cochilava e pensava sobre muitas coisas. Quando ventava forte e as portas embaixo estavam abertas, todo tipo de zunido estranho ressoava através do assoalho e pelas paredes, e rasgões do comprimento 
Jeg rejste mig og undersøgte en Byldt henne i Krogen ved Sengen efter lidt til Frokost, men fandt intet og vendte tilbage til Vinduet igen.

Gud ved, tænkte jeg, om det aldrig skal nytte mig at søge efter en Bestilling mer! Disse mange Afslag, disse halve Løfter, rene Nej, nærede og skuffede Haab, nye Forsøg, som hver Gang løb ud i intet, havde gjort det af med mit Mod. Jeg havde tilsidst søgt en Plads som Regningsbud, men var kommet forsent; desuden kunde jeg ikke skaffe Sikkerhed for femti Kroner. Der var altid et eller [4] andet til Hinder. Jeg mældte mig ogsaa til Brandkorpset. Vi stod halvhundrede Mand i Forhallen og satte Brystet ud, forat give Indtryk af Kraft og stor Dristighed. En Fuldmægtig gik omkring og besaa disse Ansøgere, følte paa deres Arme og gav dem et og andet Spørgsmaal, og mig gik han forbi, rysted blot paa Hovedet og sagde, at jeg var kasseret paa Grund af mine Briller. Jeg mødte op paany, uden Briller, jeg stod der med rynkede Bryn og gjorde mine Øjne saa hvasse som Knive, og Manden gik mig atter forbi, og han smilte, - han havde kendt mig igen. Det værste af alt var, at mine Klæder var begyndt at blive saa daarlige, at jeg ikke længer kunde fremstille mig til en Plads som et skikkeligtMenneske.

Hvor det havde gaaet jævnt og regelmæssig nedad med mig hele Tiden! Jeg stod tilsidst saa besynderlig blottet for alt muligt, jeg havde ikke engang en Kam tilbage eller en Bog at læse i, naar det blev mig for trist. Hele Sommeren udover havde jeg søgt ud paa Kirkegaardene eller op i Slotsparken, de um palmo se abriam no Morgenbladet embaixo junto à porta.

Levantei-me e examinei um embrulho no canto, junto à cama, em busca de algo para o café da manhã, mas não encontrei nada e retornei outra vez à janela.

Sabe Deus, eu pensava, se alguma vez me adiantará procurar por mais uma encomenda! Essas muitas recusas, essas meias promessas, nãos diretos, esperanças nutridas e desenganadas, novas tentativas que a cada vez davam em nada, tinham acabado com meu ânimo. Por fim, tinha procurado um posto como cobrador, mas me atrasei; além disso, eu não podia obter segurança com cinquenta coroas. Sempre havia uma coisa ou [4] outra para atrapalhar. Também me inscrevi no corpo de bombeiros. Estávamos parados na entrada, uma meia centena de homens, e estufávamos o peito para dar a impressão de força e grande audácia. Um adjunto circulava e vistoriava esses candidatos, apalpava seus braços e fazia-lhes uma pergunta ou outra, e ele passou por mim, apenas balançou a cabeça e disse que eu estava dispensado em razão de meus óculos. Apresentei-me novamente, sem óculos, fiquei ali parado com as sobrancelhas franzidas e fiz meus olhos verem como facas afiadas, e o homem passou por mim outra vez e sorriu - ele tinha me reconhecido. O pior de tudo era que minhas roupas começaram a ficar tão ruins que eu não podia mais me apresentar num lugar como um ser humano decente.

Como as coisas tinham ido, contínua e regularmente, ladeira abaixo para mim o tempo todo! Eu estava por fim tão estranhamente destituído de todo o possível, não me restara sequer um pente ou um livro para ler quando ficava demasiado triste. Por todo o verão eu tinha ido aos cemitérios ou subido 
hvor jeg sad og forfatted Artikler for Bladene, Spalte efter Spalte om de forskelligste Ting, [5] underlige Paafund, Luner, Indfald af min urolige Hjærne; i Fortvivlelse havde jeg ofte valgt de fjærneste Emner, som voldte mig lange Tiders Anstrængelse og aldrig blev optaget. Naar et Stykke var færdigt, tog jeg fat paa et nyt, og jeg blev ikke ofte nedslagen af Redaktørernes Nej; jeg sagde stadig væk til mig selv, at engang vilde det jo lykkes. Og virkelig, stundom, naar jeg havde Held med mig og fik det lidt godt til, kunde jeg faa fem Kroner for en Eftermiddags Arbejde.

Jeg rejste mig atter op fra Vinduet, gik hen til Vaskevandsstolen og dynke en Smule Vand paa mine blanke Bukseknæ, forat sværte dem lidt og faa dem til at se lidt nye ud. Da jeg havde gjort dette, stak jeg som sædvanligt Papir og Blyant i Lommen og gik ud. Jeg gled meget stille nedad Trapperne, for ikke at vække min Værtindes Opmærksomhed; der var gaaet et Par Dage, siden min Husleje forfaldt, og jeg havde ikke noget at betale med nu mere.

Klokken var ni. Vognrammel og Stemmer fyldte Luften, et uhyre Morgenkor, blandet med Fodgængernes Skridt og Smældene fra Hyrekuskenes Svøber. Denne støjende [6] Færdsel overalt oplived mig straks, og jeg begyndte at føle mig mer og mer tilfreds. Intet var fjærnere fra min Tanke end blot at gaa en Morgentur i frisk Luft. Hvad kom Luften mine Lunger ved? Jeg var stærk som en Rise og kunde standse en Vogn med min Skulder. En fin, sælsom Stemning, Følelsen af den lyse Ligegladhed, havde bemægtiget sig mig. Jeg gav mig til at iagttage de Mennesker, jeg mødte og gik forbi, læste Plakaterne paa Væggene, modtog Indtryk até o parque do castelo, onde me sentava e escrevia artigos para os jornais, coluna após coluna, sobre as coisas mais diversas, [5] invenções estranhas, caprichos e lampejos de meu cérebro inquieto; em desespero, tinha muitas vezes escolhido os temas mais remotos, que me custavam longas horas de esforço e nunca eram aceitos. Quando um estava pronto, eu iniciava um novo, e poucas vezes ficava abatido com o não dos redatores; dizia sempre a mim mesmo que um dia certamente as coisas sairiam bem. E, às vezes, de fato, quando tinha sorte e conseguia algo um pouco bom, podia ganhar cinco coroas pelo trabalho de uma tarde.

Levantei-me novamente da janela, fui até a cadeira onde estava a água para lavar e pinguei um pouquinho dela nos joelhos lustrosos de minha calça para escurecê-los um pouco e fazê-los parecer um pouco novos. Tendo feito isso, enfiei papel e lápis no bolso como de costume e saí. Deslizei muito de mansinho escada abaixo para não despertar a atenção da proprietária; tinham-se passado alguns dias desde que meu aluguel vencera, e agora eu não tinha mais como pagar.

Eram nove horas. Vozes e barulho de veículos enchiam os ares, um imenso coro matinal, misturado com o passo dos pedestres e os estampidos dos chicotes dos cocheiros de aluguel. Esse [6] trânsito barulhento por toda parte animou-me de imediato, e comecei a me sentir cada vez mais contente. Nada estava mais longe de meus pensamentos do que apenas fazer um passeio matinal ao ar fresco. O que importava o ar para meus pulmões? Eu era forte como um gigante e podia parar um veículo com meus ombros. Uma disposição sutil e estranha, um sentimento de luminosa indiferença, tinham se apoderado 
fra et Blik, slængt til mig fra en forbifarende Sporvogn, lod hver Bagatel trænge ind paa mig, alle smaa Tilfældigheder, som krydsed min Vej og forsvandt.

Naar man bare havde sig lidt til Mad en saadan lys Dag! Indtrykket af den glade Morgen overvælded mig, jeg blev uregerlig tilfreds og gav mig til at nynne af Glæde, uden nogen bestemt Grund. Ved en Slagterbutik stod en Kone med en Kurv paa Armen og spekulered paa Pølser til Middag; idet jeg passered hende, saa hun hen paa mig. Hun havde blot én Tand i Formunden. Nervøs og let paavirkelig som jeg var bleven de sidste Dage, gjorde Konens Ansigt straks et modbydeligt [7] Indtryk paa mig; den lange, gule Tand saa ud som en liden Finger, der stod op fra Kæven, og hendes Blik var endnu fuldt af Pølse, da hun vendte det mod mig. Jeg tabte med en Gang Appetiten og følte Kvalme. Da jeg kom til Basarerne, gik jeg hen til Springet og drak lidt Vand; jeg saa op - Klokken var ti i Vor Frelsers Taarn.

Jeg gik videre gennem Gaderne, drev om uden Bekymring for nogetsomhelst, standsed ved et Hjørne, uden at behøve det, bøjed af og gik en Sidegade, uden at have Ærinde derhen; jeg lod det staa til, førtes omkring I den glade Morgen, vugged mig sorgfrit frem og tilbage blandt andre lykkelige Mennesker; Luften var tom og lys, og mit Sind var uden en Skygge.

I ti Minutters Tid havde jeg stadig havt en gammel, halt Mand foran mig. Han bar de mim. Pus-me a observar as pessoas que encontrava e pelas quais passava, lia os letreiros nas paredes, recebia a impressão de um olhar lançado em minha direção vindo de um bonde que passava, deixava que cada bagatela me penetrasse, todas as pequenas casualidades que atravessavam o meu caminho e desapareciam.

Se apenas se tivesse um pouco de comida num dia tão iluminado! A impressão dessa manhã alegre me dominava, fiquei desenfreadamente contente e me pus a cantarolar de alegria sem qualquer motivo definido. Próximo a um açougue estava parada uma mulher com um cesto nos braços que pensava sobre as salsichas para o meio-dia; quando passei por ela, ela olhou para mim. Tinha só um dente na parte da frente da boca. Nervoso e facilmente impressionável como tinha me tornado nos últimos dias, o rosto da mulher me causou de imediato uma [7] impressão de nojo; esse dente comprido e amarelo parecia um pequeno dedo que se erguia do maxilar, e o seu olhar ainda estava cheio de salsicha quando o dirigiu a mim. Perdi imediatamente o apetite e senti náuseas. Quando cheguei aos bazares, fui até a fonte e tomei um pouco de água; olhei para cima - o relógio marcava dez horas na torre de Nosso Salvador.

Segui em frente pelas ruas, vagando sem preocupar-me com coisa alguma, fiquei parado numa esquina sem necessidade, dobrei-a e entrei numa rua transversal sem ter nada a fazer ali; deixei estar, caminhei pela manhã alegre, balancei-me despreocupado para a frente e para trás em meio a outras pessoas felizes; o ar estava vazio e claro, e em meu espírito não havia uma sombra sequer.

Durante dez minutos tive constantemente à minha frente um homem velho $\mathrm{e}$ 
en Byldt i den ene Haand og gik med hele sit Legeme, arbejded af al Magt, forat skyde Fart. Jeg hørte, hvor han pusted af Anstrængelse, og det faldt mig ind, at jeg kunde bære hans Byldt; jeg søgte dog ikke at indhente ham. Oppe i Grændsen mødte jeg Hans Pauli, som hilste og skyndte sig forbi. [8] Hvorfor hav de han saadant Hastværk? Jeg havde Slet ikke i Sinde at bede ham om en Krone, jeg vilde ogsaa med det allerførste sende ham tilbage et Tæppe, som jeg havde laant af ham for nogle Uger siden. Saasnart jeg var kommet lidt ovenpaa, vilde jeg ikke være nogen Mand noget Tæppe skyldig; kanske begyndte jeg allerede idag en Artikel om Fremtidens Forbrydelser eller om Viljens Frihed, hvadsomhelst, noget læseværdigt noget, som jeg vilde faa ti Kroner for mindst .... Og ved Tanken paa denne Artikel følte jeg mig med en Gang gennemstrømmet af Trang til at tage fat straks og øse af min fulde Hjærne; jeg vilde finde mig et passende Sted i Slotsparken og ikke hvile, før jeg havde faaet den færdig.

Men den gamle Krøbling gjorde fremdeles de samme sprællende Bevægelser foran mig i Gaden. Det begyndte tilsidst at irritere mig at have dette skrøbelige Menneske foran mig hele Tiden. Hans Rejse syntes aldrig at ville tage Ende; maaske havde han bestemt sig til akkurat det samme Sted som jeg, og jeg skulde hele Vejen have ham for mine $\varnothing_{j n e}$. I min Ophidselse forekom det mig, at han ved [9] hver Tvergade sagtned en Smule og ligesom vented paa, hvilken Retning jeg vilde tage, hvorpaa han igen svang Byldten højt i Luften og gik til af yderste Magt, forat faa Forsprang. Jeg gaar og ser paa dette masede Væsen og blir mer manco. Ele carregava um embrulho numa das mãos e andava com todo seu corpo, trabalhava com toda sua força, para acelerar o passo. Ouvi como respirava com esforço e ocorreu-me que poderia carregar seu embrulho; no entanto, não tentei alcançá-lo. $\mathrm{Na}$ altura da rua Grændsen, encontrei Hans Pauli, que cumprimentou e passou apressado. [8] Por que ele tinha tanta pressa? Eu não tinha em mente de forma alguma pedir-lhe uma coroa, também queria devolver-lhe na primeira ocasião o cobertor que havia tomado emprestado dele há algumas semanas. Logo que estivesse um pouco por cima, não queria dever cobertor algum a homem algum; talvez começasse já hoje um artigo sobre os crimes do futuro ou a liberdade da vontade, o que quer que fosse, algo digno de ser lido, algo pelo que queria conseguir pelo menos dez coroas... E com o pensamento nesse artigo, senti-me imediatamente atravessado pelo ímpeto de pôr mãos à obra sem demora e esvaziar meu cérebro cheio; queria encontrar um lugar adequado para mim no parque do castelo e não descansar antes de conseguir terminá-lo.

Mas o velho aleijão ainda fazia os mesmos movimentos agitados à minha frente pela rua. Por fim, começou a me irritar ter esse homem decrépito à minha frente o tempo todo. Seu percurso parecia nunca querer ter fim; talvez ele tivesse escolhido justamente o mesmo destino que eu, e por todo o caminho eu precisaria tê-lo diante de meus olhos. Em minha irritação, parecia-me que ele ia um pouco mais devagar sempre que chegava a uma [9] rua transversal e como que esperava pela direção que eu pretendia tomar, após o que voltava a balançar o embrulho alto no ar e andava com toda a força para obter vantagem. Ando e vejo esse 
og mer opfyldt af Forbittrelse mod ham; jeg følte, at han lidt efter lidt ødelagde min lyse Stemning og trak den rene, skønne Morgen med sig ned i Hæslighed med det samme. Han saa ud som et stort humpende Insekt, der med Vold og Magt vilde slaa sig til en Plads i Verden og forbeholde sig Fortouget for sig selv alene. Da vi var kommet paa Toppen af Bakken, vilde jeg ikke længer finde mig i det, jeg vendte mig mod et Butiksvindu og standsed, forat give ham Anledning til at komme væk. Da jeg efter nogle Minutters Forløb atter begyndte at gaa, var Manden foran mig igen, ogsaa han havde staaet bom stille. Jeg gjorde, uden at tænke mig om, tre fire rasende Skridt fremad, indhented ham og slog Manden paa Skulderen.

Han standsed med ét. Vi gav os begge til at stirre paa hinanden.

»En liden Skilling til Melk!« sagde han endelig og ladge Hovedet paa Siden.

[10] Se saa, nu stod jeg godt i det! Jeg følte i Lommerne og sagde:

»Til Melk ja. Hm. Det er smaat med Pengene i disse Tider, og jeg ved ikke, hvor trængende De kan være.«

»eg har ikke spist siden igaar i Drammen, « sagde Manden; »jeg ejer ikke en Øre, og jeg har ikke faaet Arbejde endnu.«

»Er De Haandværker?«

$» J a$, jeg er Naadler.»

»Hvilket?«

»Naadler. Forresten kan jeg ogsaa gøre Sko.«

»Det forandrer Sagen, « sagde jeg. »De faar vente her i nogle Minutter, saa skal jeg gaa efter lidt Penger til Dem , nogle Øre.«

Jeg gik i største Hast nedad Pilestrædet, hvor jeg vidste om en Pantelaaner i anden ser esmagado e fico cada vez mais cheio de exasperação contra ele; sentia que ele arruinava pouco a pouco meu luminoso estado de espírito e ao mesmo tempo arrastava consigo para baixo, para a feiura, a manhã pura e bela. Ele parecia um grande inseto claudicante que, com violência e força, queria abrir caminho até um lugar no mundo e ter a calçada só para si. Quando tínhamos chegado ao topo da colina, eu não queria mais me conformar com aquilo, esperei em frente a uma vitrine e me detive para lhe dar oportunidade de ir embora. Quando, decorridos alguns minutos, recomecei a caminhar, o homem estava outra vez à minha frente, ele também ficara estacado. Sem pensar, dei três ou quatro passos furiosos para frente, alcancei-o e bati no ombro do homem.

Ele parou de súbito. Começamos a nos encarar mutuamente.

- Um xelinzinho para o leite! - disse ele por fim, e colocou a cabeça para o lado.

[10] Vejam só, agora eu estava bem! Apalpei os bolsos e disse:

- Sim, para o leite. Hm. O dinheiro anda escasso nesses tempos e não sei o quão necessitado o senhor pode estar.

- Não como desde ontem, em Drammen - disse o homem; - não tenho um vintém e ainda não consegui trabalho.

- O senhor é artesão?

- Sim, sou acabador de calçados.

- O quê?

- Acabador de calçados. De mais a mais, também sei fazer sapatos.

- Isso muda as coisas - eu disse. - Espere aqui alguns minutos, que vou buscar um pouco de dinheiro para o senhor, alguns vinténs.

Desci na maior pressa pela Pilestrædet, onde eu sabia de um penhorista no segun- 
Etage; jeg havde forøvrigt aldrig været hos ham før. Da jeg kom ind i Porten, trak jeg skyndsomt min Vest af, rulled den sammen og stak den under Armen; derpaa gik jeg opad Trappen og banked paa til Sjappen. Jeg bukked og kasted Vesten paa Disken.

»Halvanden Krone, sagde Manden.

[11] »Ja ja, Tak, « svared jeg. »Havde det ikke været det, at den begyndte at blive lidt for knap til mig, saa vilde jeg ikke have skilt mig ved den, naturligvis."

Jeg fik Pengene og Sedlen og begav mig tilbage. Det var i Grunden et udmærket Paafund, dette med Vesten; jeg vilde endog faa Penge tilovers til en rigelig Frokost, og inden Aften skulde saa min Afhandling om Fremtidens Forbrydelser være istand. Jeg begyndte paa Stedet at finde Tilværelsen blidere, og jeg skyndte mig tilbage til Manden, forat faa ham fra Haanden.

»Værsaagod! « sagde jeg til ham. »Det glæder mig, at De har henvendt Dem til mig forst."

Manden tog Pengene og begyndte at mønstre mig med $\varnothing_{\text {jnene. Hvad stod han }}$ og stirred efter? Jeg havde det Indtryk, at han især undersøgte mine Bukseknæ, og jeg blev træt af denne Uforskammethed. Troed Slyngelen, at jeg virkelig var saa fattig som jeg saa ud for? Havde jeg maaske ikke saagodtsom begyndt at skrive paa en Artikel til ti Kroner? Overhovedet frygted jeg ikke for Fremtiden, jeg havde mange Jærn i Ilden. [12] Hvad kom det saa et vild fremmed Menneske ved, om jeg gav bort en Drikkeskilling paa en saadan lys Dag? Mandens Blik irritered mig, og jeg beslutted mig til at give ham en Irettesættelse, inden jeg forlod ham. Jeg trak paa Skuldrene og sagde: do andar; aliás, eu nunca estivera antes em seu estabelecimento. Quando passei pelo portão, tirei meu colete na maior pressa, enrolei-o e meti-o debaixo do braço; em seguida, subi as escadas e bati à porta da lojeca. Fiz uma reverência e joguei o colete sobre o balcão.

- Uma coroa e meia - disse o homem.

[11] - Sim, sim, obrigado - respondi. Não tivesse ele começado a ficar um pouco apertado para mim, eu não iria querer me desfazer dele, naturalmente.

Peguei o dinheiro e o recibo e me encaminhei de volta. Era no fundo uma ideia excelente, essa do colete; eu até conseguiria dinheiro de sobra para um café suntuoso e, até a tardinha, meu ensaio sobre os crimes do futuro também poderia estar pronto. De imediato comecei a achar a existência mais suave, e me apressei para voltar até o homem a fim de me ver livre dele.

- Aqui está! - disse-lhe. - Alegra-me que o senhor tenha se dirigido a mim primeiro.

O homem pegou o dinheiro e começou a me medir com os olhos. Por que estava ali parado, me olhando? Tive a impressão de que examinava sobretudo os joelhos das minhas calças, e fiquei cansado de sua impertinência. Será que o patife acreditava que eu era realmente tão pobre quanto parecia? Não tinha praticamente começado a escrever um artigo de dez coroas? De qualquer modo, eu não tinha medo do futuro, ainda tinha muita lenha para queimar. [12] O que importava a esse homem completamente desconhecido que eu desse uma gorjeta num dia tão iluminado? O olhar do homem me irritava, e me decidi a passar-lhe uma reprimenda antes de deixá-lo. Encolhi os ombros e disse: 
»Min gode Mand, De har lagt Dem til den stygge Uvane at glo en Mand paa Knæerne, naar han giver Demen Krones Penge.«

Han ladge Hovedet helt tilbage $\bmod \mathrm{Mu}-$ ren og spærred Munden op. Der arbejded noget bag hans Stodderpande, han tænkte ganske vist, at jeg vilde narre ham paa en eller anden Maade, og han rakte mig Pengene tilbage.

Jeg stamped i Gaden og svor paa, at han skulde beholde dem. Indbildte han sig, at jeg vilde have alt det Bryderi for ingenting? Naar alt kom til alt skyldte jeg ham maaske denne Krone, jeg havde det med at huske en gammel Grld, han stod foran et retskaffent Menneske, ærlig ud i Fingerspidserne. Kortsagt, Pengene var hans . . . A Aa, ikke noget at takke for, det havde været mig en Glæde. Farvel.

Jeg gik. Endelig havde jeg denne værkbrudne Plageaand afvejen, og jeg kunde være [13] uforstyrret. Jeg tog atter ned gennem Pilestrædet og standsed udenfor en Husholdningshandel. Der laa fuldt op af Mad i Vinduet, og jeg bestemte mig til at gaa ind og faa mig lidt med paa Vejen.

»Et Stykke Ost og et Franskbrød!« sagde jeg og slængte min Halvkrone paa Disken.

»Ost og Brød for altsammen?« spurgte Konen ironisk, uden at se paa mig.

»For hele femti Øre ja,« svared jeg uforstyrret.

Jeg fik mine Sager, sagde yderst høfligt Godmorgen til den gamle, fede Kone og begav mig sporenstrængs opad Slotsbakken til Parken. Jeg fandt mig en Bænk for mig
- Meu bom homem, o senhor adotou o péssimo hábito de cravar os olhos nos joelhos de um homem quando ele lhe dá uma coroa.

Ele colocou a cabeça inteiramente para trás contra o muro e escancarou a boca. Alguma coisa trabalhava por trás de sua testa de mendigo; ele certamente pensou que eu queria enganá-lo de uma forma ou de outra e me estendeu o dinheiro de volta.

Bati o pé no chão e jurei que ele podia ficar com ele. Será que ele imaginava que eu tinha tido toda aquela trabalheira por nada? No fim das contas, talvez eu lhe devesse essa coroa; eu costumava me lembrar de uma velha dívida; ele estava diante de um homem honrado, honesto até as pontas dos dedos. Em suma, o dinheiro era dele... Ah, não há nada a agradecer, foi um prazer para mim. Adeus.

Segui em frente. Finalmente tinha tirado aquela praga reumática do caminho e podia ficar [13] em paz. Desci novamente pela Pilestrædet e fiquei parado do lado de fora de uma mercearia. A vitrine estava repleta de alimentos, e decidi entrar e comprar um pouco para comer no caminho.

- Um pedaço de queijo e um pão francês! - eu disse, jogando minha meia coroa no balcão.

- Queijo e pão por tudo isso? - perguntou a mulher ironicamente, sem me olhar.

- Por todos os cinquenta $o r e^{4}, \operatorname{sim}$ - respondi sem me perturbar.

Recebi minhas coisas, dei um bom-dia extremamente gentil à mulher velha e gorda $\mathrm{e}$ me dirigi sem demora até o parque subindo pela colina do castelo. Escolhi um banco

4 A centésima parte de uma coroa, a unidade monetária dos países escandinavos. (N.T.) 
selv og begyndte at gnave graadigt af min Niste. Det gjorde godt; det var længe siden jeg havde faaet et saa rundeligt Maaltid, og jeg følte lidt efter lidt den samme mætte Ro i mig, som én føler efter en lang Graad. Mit Mod steg stærkt; det var mig ikke længer nok at skrive en Artikel om noget saa enkelt og ligetil som Fremtidens Forbrydelser, som desuden hvemsomhelst kunde gætte sig til, ligefrem læse sigtil i Historien; jeg følte mig istand til en større Anstrængelse, jeg var i [14] Stemning til at overvinde Vanskeligheder, og jeg bestemte mig for en Afhandling i tre Afsnit om den filosofiske Erkendelse. Naturligvis vilde jeg faa Lejlighed til at knække ynkeligt nogle af Kants Sofismer .... Da jeg vilde tage mine Skrivesager frem og begynde Arbejdet, opdaged jeg, at jeg ikke længer havde nogen Blyant hos mig; jeg havde glemt den efter mig i Pantelaanersjappen; min Blyant laa i Vestelommen.

Herregud hvor dog alting havde Lyst til at gaa forkært for mig! Jeg banded nogle Gange, rejste mig op fra Bænken og drev frem og tilbage i Gangene. Det var meget stille overalt; langt borte, ved Dronningens Lysthus, rulled et Par Barnepiger sine Vogne omkring, ellers var der ikke et Menneske at se noget Sted. Jeg var dygtig forbittret i Sind og spadsered som en rasende foran min Bænk. Hvor mærkelig vrangt gik det dog ikke paa alle Kanter! En Artikel i tre Afsnit skulde ligefrem strande paa den simple Ting, at jeg ikke havde et Stykke ti Øres Blyant i Lommen! Hvad om jeg gik ned i Pilestrædet igen og fik min Blyant tilbageleveret? Der vilde endda blive Tid til at [15] faa et godt Stykke færdigt, inden de spadserende begyndte at fylde Parken. Der var ogsaa saa meget, som afhang af denne para mim e comecei a roer vorazmente o meu lanche. Isso me fez bem; fazia muito tempo que eu tinha feito uma refeição tão abundante, e sentia pouco a pouco a mesma tranquilidade saciada que as pessoas sentem após um longo tempo chorando. Meu ânimo melhorou intensamente; não me bastava mais escrever um artigo sobre algo tão simples e fácil como os crimes do futuro, que, ademais, qualquer um poderia deduzir simplesmente lendo a história; sentia-me capaz de um esforço maior, estava num [14] estado de espírito para superar dificuldades, e me decidi por um estudo em três partes sobre o conhecimento filosófico. Naturalmente, teria ocasião de abater miseravelmente alguns dos sofismas de Kant... Quando quis sacar meus apetrechos de escrita e começar o trabalho, me dei conta de que há muito tempo não tinha mais lápis algum comigo; eu o tinha esquecido na lojeca do penhorista; meu lápis estava no bolso do colete.

Por Deus, como tudo estava tomando gosto em dar errado para mim! Praguejei algumas vezes, levantei-me do banco e circulei para cima e para baixo pelas alamedas. Estava muito quieto por toda parte; ao longe, próximo à casa de veraneio da rainha, algumas babás empurravam seus carrinhos; no mais, não havia uma pessoa à vista em parte alguma. Eu estava extremamente amargurado em meu íntimo e passeava como um louco diante de meu banco. O quão estranhamente às avessas não estavam indo as coisas por todos os cantos! Um artigo em três partes podia até fracassar pelo simples fato de eu não ter no bolso um pedaço de lápis de dez øre! E se eu fosse novamente até a Pilestrædet e obtivesse meu lápis de volta? Ainda sobraria tempo para [15] terminar um bom pedaço antes 
Afhandling om den filosofiske Erkendelse, maaske flere Menneskers Lykke, ingen kunde vide det. Jeg sagde til mig selv, at den kanske vilde blive til stor Hjælp for mange unge Mennesker. Ret betænkt vilde jeg ikke forgribe mig paa Kant; jeg kunde jo undgaa det, jeg behøved blot at gøre en ganske umærkelig Bøjning, naar jeg kom til Spørgsmaalet Tid og Rum; men Renan vilde jeg ikke svare for, gamle Sogneprest Renan .... Under alle Omstændigheder galdt det at gøre en Artikel paa saa og saa mange Spalter; den ubetalte Husleje, Værtindens lange Blik om Morgenen, naar jeg traf hende i Trapperne, pinte mig hele Dagen og dukked frem igen endog i mine glade Stunder, naar jeg ellers ikke havde en mørk Tanke. Dette maatte jeg have en Ende paa. Jeg gik hurtigt ud af Parken, forat hente min Blyant hos Pantelaaneren.

Da jeg kom ned i Slotsbakken, indhented jeg to Damer, som jeg gik forbi. Idet jeg passered dem, strejfed jeg den enes Ærme, jeg saa op, hun havde et fyldigt, lidt blegt [16] Ansigt. Med ét blusser hun og blir forunderlig skøn, jeg ved ikke hvorfor, maaske af et Ord, hun hører af en forbigaaende, maaske blot af en stille Tanke hos hende selv. Eller skulde det være fordi jeg berørte hendes Arm? Det høje Bryst bølger heftigt nogle Gange, og hun klemmer Haanden haardt om Parasolskaftet. Hvad gik der af hende?

Jeg standsed og lod hende komme foran mig igen, jeg kunde ikke i Øjeblikket gaa videre, det hele forekom mig saa besynderligt. Jeg var i et pirreligt Lune, ærgerlig paa mig selv for Hændelsen med Blyanten que os passeantes começassem a encher o parque. Também havia tanta coisa que dependia desse estudo sobre o conhecimento filosófico, talvez a felicidade de muitos seres humanos, ninguém podia saber. Disse a mim mesmo que talvez fosse de grande ajuda para muitos jovens. Pensando bem, eu não maltrataria Kant; eu poderia evitar isso, precisaria apenas fazer um desvio inteiramente imperceptível quando chegasse às questões do tempo e do espaço; mas não responderia por Renan, o velho sacerdote Renan... Fosse lá como fosse, o importante era produzir um artigo de tantas e tantas colunas; o aluguel não pago e o olhar demorado da proprietária quando a encontrava nas escadas de manhã atormentavam-me o dia inteiro e emergiam novamente inclusive em meus momentos felizes, quando de costume não tinha pensamentos sombrios. Eu tinha que dar um fim naquilo. Saí depressa do parque para buscar meu lápis com o penhorista.

Quando desci a colina do castelo, alcancei duas moças, que ultrapassei. Ao passar, rocei a manga de uma delas, ergui os olhos, ela tinha um [16] rosto cheio, ligeiramente pálido. De súbito, ela enrubesceu e ficou surpreendentemente bonita, eu não sabia por que, talvez por uma palavra que tivesse ouvido de um passante, talvez apenas por um pensamento silencioso consigo mesma. $\mathrm{Ou}$ poderia ser porque toquei seu braço? O busto elevado ondulou violentamente algumas vezes, e ela apertou firmemente as mãos em torno do cabo da sombrinha. O que é que ela tinha?

Fiquei parado e a deixei passar outra vez à minha frente, no momento não podia ir adiante, aquilo tudo me parecia demasiado estranho. Estava com um humor irritável, aborrecido comigo mesmo por causa do 
og i høj Grad ophidset af al den Mad, jeg havde nydt paa tom Mave. Med en Gang tager min Tanke ved et lunefuldt Indfald en mærkelig Retning, jeg føler mig greben af en sælsom Lyst til at gøre denne Dame bange, følge efter hende og fortrædige hende paa en eller anden Maade. Jeg indhenter hende atter og gaar hende forbi, vender mig pludselig om og møder hende Ansigt til Ansigt, forat iagttage hende. Jeg staar og ser hende ind i Øjnene og hitter paa Stedet et Navn, som jeg aldrig havde hørt, et Navn med en glidende, nervøs Lyd: Ylajali. Da hun var kommet mig [17] ganske nær, retter jeg mig ivejret og siger indtrængende:

\section{»De mister Deres Bog, Frøken.«}

Jeg kunde høre, hvor mit Hjærte slog hørligt, da jeg sagde det.

»Min Bog?« spørger hun sin Ledsagerinde. Og hun gaar videre.

Min Ondskabsfuldhed tiltog, og jeg fulgte efter Damen. Jeg var mig i Øjeblikket fuldt bevidst, at jeg begik gale Streger, uden at jeg kunde gøre noget ved det; min forvirrede Tilstand løb af med mig og gav mig de mest forrykte Indskydelser, som jeg lystred efter Tur. Det nytted ikke, hvormeget jeg sagde til mig selv, at jeg bar mig idiotisk ad, jeg gjorde de dummeste Grimaser bag Damens Ryg, og jeg hosted rasende nogle Gange, idet jeg passered hende. Saaledes vandrende ganske sagte fremad, altid i nogle Skridts Forspring, følte jeg hendes Øjne i min Ryg, og jeg dukked mig uvilkaarlig ned af Skam over at have været hende til Plage. Lidt efter lidt fik jeg en forunderlig Fornemmelse af at være langt borte, andre Steder henne, jeg havde en halvt ubestemt Følelse af, at det [18] ikke var mig, som gik der paa Stenfliserne og dukked mig ned. incidente com o lápis e agitado em grau extremo por toda a comida que ingerira de estômago vazio. De imediato, meu pensamento toma uma direção singular devido a uma ideia caprichosa, sinto-me tomado por um prazer esquisito de assustar aquela moça, segui-la e incomodá-la de uma forma ou de outra. Alcanço-a novamente e a ultrapasso, viro-me de súbito e fico frente a frente com ela para observá-la. Fico parado e a olho dentro dos olhos e encontro ali mesmo um nome que nunca tinha ouvido, um nome com um som deslizante, nervoso: Ilaiáli. Quando ela tinha chegado [17] bem perto de mim, aprumo-me e digo de modo invasivo:

- Perdeste teu livro, senhorita.

Pude ouvir como meu coração batia perceptivelmente ao dizer isso.

- Meu livro? - ela pergunta à sua acompanhante. E segue em frente.

Minha malevolência aumentou, e eu as segui. Naquele momento estava plenamente consciente de que cometia doidas traquinices, sem que pudesse fazer algo a respeito; meu estado confuso me fazia perder o controle e me dava as mais loucas ideias, às quais obedecia uma após a outra. Por mais que dissesse a mim mesmo que estava me comportando de maneira idiota, isso de nada adiantou; fiz as mais estúpidas caretas pelas costas da moça e tossi furiosamente algumas vezes ao passar por ela. Avançando bem lentamente dessa forma, sempre com alguns passos de vantagem, senti seus olhos em minhas costas e abaixei-me involuntariamente de vergonha por tê-la atormentado. Pouco a pouco adquiri a sensação de estar bem longe, em outros lugares, tinha um sentimento meio indefinido de que [18] não era eu que caminhava sobre as lajotas de pedra e me abaixava. 
Nogle Minutter efter er Damen kommet til Paschas Boglade, jeg har allerede standset ved det første Vindu, og idet hun gaar forbi mig, træder jeg frem og gentager:

»De mister Deres Bog, Frøken.«

»Nej, hvilken Bog?« siger hun i Angst. $»$ Kan du forstaa, hvad det er for en Bog, han taler om?«

Og hun standser. Jeg gotter mig grusomt over hendes Forvirring, denne Raadvildhed i hendes $\varnothing$ jne henrykker mig. Hendes Tanke kan ikke fatte min lille desperate Tiltale; hun har slet ingen Bog med, ikke et eneste Blad af en Bog, og alligevel leder hun i sine Lommer, ser sig gentagne Gange ind i Hænderne, vender Hovedet og undersøger Gaden bag sig, anstrænger sin lille ømtaalige Hjærne til det yderste, forat finde ud, hvad det er for en Bog, jeg taler om. Hendes Ansigt skifter Farve, har snart det ene, snart det andet Udtryk, og hun aander ganske hørligt; selv Knapperne $\mathrm{i}$ hendes Kjole synes at stirre paa mig som en Række forfærdede $\varnothing_{j n e .}$

[19]»Bryd dig ikke om ham, « siger hendes Ledsagerske og trækker hende i Armen; »han er jo fuld; kan du ikke se, at Manden er fuld!

Saa fremmed, som jeg i dette Øjeblik var for mig selv, saa fuldstændig et Bytte for sære, usynlige Indflydelser, foregik der intet omkring mig, uden at jeg lagde Mærke til det. En stor brun Hund sprang tværs over Gaden, henimod Lunden og ned til Tivoli; den havde et ganske smalt Halsbaand af Nysølv. Højere op i Gaden aabnedes et Vindu i anden Etage, og en Pige ladge sig ud af det med opbrættede Ærmer og gav sig til at pudse Ruderne paa Ydersiden. Intet undgik min Opmærksomhed, jeg var klar og aandsnærværende, alle Ting strømmed ind paa mig med en skinnende Tydelighed,
Alguns minutos depois a moça chegou à livraria do Pascha; eu já estava parado diante da primeira vitrine e, enquanto ela passa por mim, dou um passo à frente e repito:

- Perdeste teu livro, senhorita.

- Não, que livro? - diz ela com medo. Consegues entender de que livro ele está falando?

E ela fica parada. Alegro-me cruelmente com a sua desorientação, essa perplexidade em seus olhos me entusiasma. Seu pensamento não consegue compreender minha pequena abordagem desesperada; ela não tem livro algum consigo, nem sequer uma única folha de um livro, e, mesmo assim, procura nos bolsos, olha repetidas vezes para as mãos, volta a cabeça e averigua a rua atrás de si, força o pequeno cérebro sensível ao extremo para descobrir de que livro estou falando. Seu rosto muda de cor, tem ora uma ora outra expressão e ela respira de maneira claramente audível; mesmo os botões de seu vestido parecem me encarar como uma fileira de olhos assustados.

[19] - Não dê atenção a ele - disse sua companheira e puxou-a pelo braço; - ele está bêbado; será que você não vê que ele está bêbado?

Por mais estranho que eu fosse a mim mesmo naquele momento, por mais que fosse uma presa completa de influências extravagantes e invisíveis, nada acontecia a meu redor sem que eu percebesse. Um grande cachorro marrom atravessou a rua correndo nas proximidades do bosque e desceu rumo ao parque de diversões; ele tinha uma coleira bem estreita de metal-branco. Mais acima na rua, abriu-se a janela no segundo andar e uma moça, com as mangas arregaçadas, inclinou-se para fora e pôs-se a limpar as vidraças pelo lado externo. Nada escapava à minha atenção, eu 
som om der pludselig var bleven et stærkt Lys omkring mig. Damerne foran mig havde begge en blaa Fuglevinge i Hatten og et skotsk Silkebaand om Halsen. Det faldt mig ind, at de var Søstre.

De bøjed af og standsed ved Cislers Musikhandel og talte sammen. Jeg standsed ogsaa. Derpaa kom de begge to tilbage, gik den samme Vej, som de var kommet, passered [20] mig igen, drejed om Hjørnet ved Universitetsgaden og gik lige op til St. Olafs Plads. Jeg var dem hele Tiden saa nær i Hælene som jeg turde. De vendte sig engang og sendte mig et halvt bange, halvt nysgærrigt Blik, og jeg saa ingen Fortørnelse i deres Miner og ingen rynkede Bryn. Denne Taalmodighed med mine Plagerier gjorde mig meget skamfuld, og jeg slog Øjnene ned. Jeg vilde ikke længer være dem til Fortræd, jeg vilde af ren Taknemmelighed følge dem med Øjnene, ikke tabe dem afsyne, helt til de gik ind et Sted og blev borte.

Udenfor Numer 2, et stort fire Etages Hus, vendte de sigendnu engang, hvorpaa de gik ind. Jeg læned mig til en Gaslygte ved Fontænen og lytted efter deres Skridt i Trapperne; de døde hen i anden Etage. Jeg træder frem fra Lygten og ser opad Huset. Da sker der noget besynderligt. Gardinerne bevæger sig højt oppe, et Øjeblik efter aabnes et Vindu, et Hoved stikker ud, og to sært seende Øjne hviler paa mig. Ylajali! sagde jeg halvhøjt, og jeg følte, at jeg blev rød. Hvorfor raabte hun ikke om Hjælp? Hvorfor stødte hun ikke til en af Blomsterpotterne og [21] rammed mig i Hovedet, mantinha minha lucidez e a minha presença de espírito, todas as coisas afluíam a mim com uma clareza fulgurante, como se de repente se tivesse feito uma luz forte ao meu redor. Ambas as moças à minha frente tinham uma asa de pássaro azul no chapéu e uma fita de seda escocesa em torno do pescoço. Ocorreu-me que eram irmãs.

Elas dobraram e ficaram paradas em frente à loja de música de Cisler, conversando entre si. Também parei. Em seguida as duas voltaram pelo mesmo caminho que haviam percorrido, passaram [20] novamente por mim, viraram na esquina da Rua da Universidade e subiram direto até a praça de Santo Olavo. O tempo todo eu estava tão próximo de seus calcanhares quanto podia. Elas se voltaram uma vez e me dirigiram um olhar meio receoso, meio curioso, e eu não vi nenhuma indignação em seus rostos e nenhuma sobrancelha franzida. A paciência delas com minhas importunações me deixou bastante envergonhado e baixei os olhos. Eu não queria ser um incômodo para elas por mais tempo, queria segui-las com os olhos por pura gratidão, não as perder de vista, até que entrassem em algum lugar e desaparecessem.

Do lado de fora do número 2 , um grande prédio de quatro andares, elas pararam mais uma vez e em seguida entraram. Apoiei-me num lampião a gás perto do chafariz e fiquei à escuta de seus passos na escadaria; eles se extinguiram no segundo andar. Afasto-me do lampião e ergo os olhos para o prédio. Então acontece algo estranho. As cortinas se movem muito alto e, um instante depois, abre-se uma janela, aparece uma cabeça e pousam sobre mim dois olhos que encaram de modo singular. Ilaiáli!, eu disse a meia-voz, e senti que enrubescia. Por que ela não pedia ajuda? Por que não empurrava 
eller sendte nogen ned, forat jage mig væk? Vi staar og ser hinanden ind i Øjnene uden at røre os; det varer et Minut; der skyder Tanker mellem Vinduet og Gaden, og der siges ikke et Ord. Hun vender sigom, det giver et Ryk i mig, et fint Stød gennem mit Sind; jeg ser en Skulder, der drejer sig, en Ryg, der forsvinder indad Gulvet. Denne langsomme Gang bort fra Vinduet, Betoningen i denne Bevægelse med Skuldren var som et Nik til mig; mit Blod fornam denne fine Hilsen, og jeg følte mig i samme Stund vidunderlig glad. Saa vendte jeg om og gik nedad Gaden.

Jeg turde ikke se mig tilbage og vidste ikke, om hun atter var kommet til Vinduet; efterhvert som jeg overvejed dette Spørgsmaal, blev jeg mer og mer urolig og nervøs. Formodentlig stod hun i dette Øjeblik og fulgte nøje alle mine Bevægelser, og det var paa ingen Maade til at holde ud at vide sig saaledes undersøgt bagfra. Jeg strammed mig op saa godt jeg kunde og gik videre; det begyndte at rykke i mine Ben, min Gang blev ustø, fordi jeg med Vilje vilde gøre den smuk. Forat synes rolig og ligegyldig slængte jeg [22] meningsløst med Armene, spytted i Gaden og satte Næsen ivejret; men intet hjalp. Jeg følte stadig de forfølgende $\varnothing$ jne i min Nakke, og det løb mig koldt gennem Kroppen. Endelig redded jeg mig ind i en Sidegade, hvorfra jeg tog Vejen ned i Pilestrædet, forat faa fat paa min Blyant.

Jeg havde ingen Møje med at faa den tilbageleveret. Manden bragte mig Vesten selv og bad mig undersøge alle Lommerne um vaso de flores e [21] me acertava na cabeça ou mandava alguém para baixo para me afugentar? Ficamos parados e nos olhamos um ao outro nos olhos, sem nos mover; isso dura um minuto; pensamentos disparam entre a janela e a rua, e não se diz uma palavra. Ela se vira, isso me dá um golpe, um choque sutil que atravessa meu espírito; vejo um ombro que se volta, um dorso que some em direção ao interior do quarto. Esse andar vagaroso para longe da janela, a ênfase nesse movimento do ombro, foi como um aceno de cabeça para mim; meu sangue percebeu esse delicado cumprimento e, no mesmo instante, me senti maravilhosamente alegre. Então me virei e desci a rua.

Eu não podia olhar para trás e não sabia se ela tinha voltado novamente à janela; à medida que refletia sobre essa questão eu ficava cada vez mais inquieto e mais nervoso. Era provável que naquele momento ela estivesse parada e seguisse minunciosamente todos os meus movimentos, e não era de se suportar de maneira alguma saber que se era examinado assim pelas costas. Endireitei-me o melhor que podia e segui em frente; minhas pernas começaram a repuxar, meu andar se tornou cambaleante porque eu queria propositalmente fazê-lo bonito. A fim de parecer tranquilo e indiferente, balancei [22] absurdamente os braços, cuspi na rua e empinei o nariz; mas nada ajudou. Sentia constantemente os olhos perseguidores em minha nuca e arrepios percorriam meu corpo. Por fim me salvei numa rua lateral, de onde tomei o caminho descendo a Pilestrædet para pegar o meu lápis.

Não tive qualquer dificuldade para reavê-lo. O homem trouxe-me o colete em pessoa e pediu-me para examinar todos os 
med det samme; jeg fandt ogsaa et Par Laanesedler, som jeg stak til mig, og takked den venlige Mand for hans Imødekommenhed. Jeg blev mer og mer tiltalt af ham, det blev mig i samme Stund meget om at gøre at give dette Menneske et godt Indtryk af mig. Jeg gjorde et Slag henimod Døren og vendte atter tilbage til Disken, som om jeg havde glemt noget; jeg mente at skylde ham en Forklaring, en Oplysning, og jeg gav mig til at nynne, forat gøre ham opmærksom. Da tog jeg Blyanten i Haanden og holdt den ivejret.

Det kunde ikke falde mig ind, sagde jeg, at gaa lange Veje for en hvilkensomhelst saadan Blyant; men med denne var det en anden Sag, en egen Aarsag. Saa ringe som den saa ud, [23] havde denne Blyantstump simpelthen gjort mig til det, jeg var i Verden, saa at sige sat mig paa min Plads i Livet...

Jeg sagde ikke mer. Manden kom helt hen til Disken.

»a saa?« sagde han og saa nysgærrigt paa mig.

Med den Blyant, fortsatte jeg koldblodigt, havde jeg skrevet min Afhandling om den filosofiske Erkendelse i tre Bind. Om han ikke havde hørt den omtale?

Og Manden synes nok, at han havde hørt Navnet, Titlen.

Ja, sagde jeg, den var af mig, den! Saa det maatte endelig ikke forundre ham, at jeg vilde have den lille Stump Blyant tilbage; den havde altfor stort Værd for mig, den var mig næsten som et lidet Menneske. Forresten var jeg ham oprigtig taknemmelig for hans Velvilje, og jeg vilde huske ham for den - jo, jo, jeg vilde virkelig huske ham for den; et Ord var et Ord, den Slags Mand var jeg, og han fortjente det. Farvel.

Jeg gik til Døren med en Holdning, som om jeg kunde anbringe en Mand i en høj bolsos imediatamente; encontrei também alguns recibos de penhor, que meti nos bolsos, e agradeci o amável homem por sua gentileza. Ele me agradava cada vez mais, ao mesmo tempo que me era muito importante dar-lhe uma boa impressão a meu respeito. Cheguei quase até a porta e retornei ao balcão, como se tivesse esquecido alguma coisa; tinha em mente que lhe devia uma explicação, um esclarecimento, e comecei a cantarolar, para chamar sua atenção. Então peguei o lápis na mão e o segurei alto.

Não me ocorreria, disse, percorrer longos caminhos por um lápis qualquer; mas aquele era outra coisa, uma causa particular. Por menor que parecesse, [23] aquele toco de lápis tinha feito de mim quem eu era no mundo, tinha por assim dizer me colocado em meu lugar na vida...

Eu não disse mais nada. O homem achegou-se ao balcão.

- Ah é? - disse ele, olhando-me curioso.

Com esse lápis, continuei com sangue-frio, escrevi meu tratado em três volumes sobre o conhecimento filosófico. Será que ele não tinha ouvido falar dele?

E pareceu mesmo ao homem que tinha ouvido o nome, o título.

Sim, eu disse, ele era meu! Assim, não devia por fim espantá-lo que eu quisesse ter de volta o pequeno toco de lápis; ele tinha um valor grande demais para mim, era-me como um pequeno ser humano. De resto, eu lhe era sinceramente grato por sua boa vontade, e iria lembrar-me dele por isso - sim, sim, realmente me lembraria dele por isso; uma palavra era uma palavra, eu era esse tipo de homem, e ele merecia isso. Adeus.

Dirigi-me à porta com a atitude de alguém que poderia colocar um homem 
Post i Brandvæsenet. Den skikkelige Pantelaaner [24] bukked to Gange for mig, idet jeg fjærned mig, og jeg vendte mig endnu engang og sagde Farvel.

I Trappen mødte jeg en Kone, som bar en Vadsæk i Haanden. Hun trykked sig ængsteligt til Siden, forat give mig Plads, og jeg greb uvilkaarligt i Lommen efter noget at give hende; da jeg ikke fandt nogen Ting, blev jeg flau og gik hende duknakket forbi. Lidt efter hørte jeg, at ogsaa hun banked paa til Sjappen; der var et Staaltraadsprinkel paa Døren, og jeg kendte straks igen den klirrende Lyd, naar et Menneskes Knoger berørte det.

Solen stod i Syd, Klokken var ontremt tolv. Byen begyndte at komme paa Benene, det nærmed sig Spadsertiden, og hilsende og leende Folk bølged op og ned ad Karl Johan. Jeg klemte Albuerne i Siden, gjorde mig liden og slap ubemærket forbi nogle Bekendte, som havde indtaget et Hjørne ved Universitetet, forat beskue de forbigaaende. Jeg vandred opad Slotsbakken og faldt i Tanker.

Disse Mennesker, jeg mødte, hvor let og lystigt vugged de ikke sine lyse Hoveder og svinged siggennem Livet som gennem en [25] Balsal! Der var ikke Sorg i et eneste Øje, jeg saa, ingen Byrde paa nogen Skulder, kanske ikke en skyet Tanke, ikke en liden hemmelig Pine i noget af disse glade Sind. Og jeg gik der lige ved Siden af disse Mennesker, ung og nys udsprungen, og jeg havde allerede glemt, hvordan Lykken saa ud! Jeg dægged for mig selv med denne Tanke og fandt, at der var skeet mig gruelig Uret. Hvorfor havde de sidste Maaneder faret saa mærkelig haardt frem med mig? num alto posto nos bombeiros. $\mathrm{O}$ honesto penhorista [24] saudou-me inclinando-se duas vezes, enquanto eu me afastava, e me voltei mais uma vez e disse adeus.

Nas escadas passei por uma mulher que levava um alforje nas mãos. Ela se esquivou receosamente para o lado a fim de me dar lugar, e apalpei de modo involuntário os bolsos em busca de algo para lhe dar; como não encontrei coisa alguma, fiquei envergonhado e passei cabisbaixo por ela. Pouco depois, ouvi que ela também bateu à porta da lojeca; havia uma grade de arame de aço na porta e reconheci de imediato outra vez o ruído tilintante de quando o nó do dedo de uma pessoa a tocava.

O sol estava no sul, era por volta de meio-dia. A cidade começava a pôr-se de pé, aproximava-se a hora dos passeios, e as pessoas, cumprimentando-se e rindo, ondulavam para cima e para baixo pela Karl Johan. Apertei os cotovelos contra os flancos, me fiz pequeno e me esquivei despercebido de alguns conhecidos que haviam tomado conta de uma esquina próxima à universidade para observar os passantes. Subi pela colina do castelo e me entreguei aos pensamentos.

Essas pessoas que eu encontrava - com que leveza e alegria meneavam suas cabeças iluminadas e se balançavam pela vida, como se fosse um [25] salão de baile! Não havia nenhuma aflição em um único olhar, eu vi, nenhum fardo sobre ombro algum, talvez nenhum pensamento nublado, nenhum pequenino tormento secreto em nenhum desses espíritos alegres. E eu caminhava bem ao lado dessas pessoas, jovem e recém-desabrochado, e já tinha esquecido qual era a aparência da felicidade! Eu afagava esse pensamento cá comigo e descobri que me acontecera uma horrível injustiça. Por que 
Jeg kendte slet ikke mit lyse Sind igen, og jeg havde de underligste Plager paa alle Kanter. Jeg kunde ikke sætte mig paa en Bænk for mig selv eller røre min Fod noget Sted hen, uden at blive overfaldt af smaa og betydningsløse Tilfældigheder, jammerlige Bagateller, som trængte ind i mine Forestillinger og spredte mine Kræfter for alle Vinde. En Hund, som strøg mig forbi, en gul Rose i en Herres Knaphul, kunde sætte mine Tanker i Vibren og optage mig for længere Tid. Hvad var det, som fejled mig? Havde Herrens Finger pegt paa mig? Men hvorfor just paa mig? Hvorfor ikke lige saa godt paa en Mand i Sydamerika, for den Skyld? Naar jeg overvejed Tingen, blev det [26] mig mer og mer ubegribeligt, at netop jeg skulde være udset til Prøveklud for Guds Naades Lune. Det var en noksaa ejendommelig Fremgangsmaade at springe over en hel Verden, forat række mig; der var nu baade Antikvarboghandler Pascha og Dampskibsekspeditør Hennechen.

Jeg gik og drøfted denne Sag og kunde ikke blive den kvit, jeg fandt de vægtigste Indvendinger mod denne Herrens Vilkaarlighed at lade mig undgælde for alles Skyld. Endog efterat jeg havde fundet mig en Bænk og sat mig ned, vedblev dette Spørgsmaal at sysselsætte mig og hindre mig fra at tænke paa andre Ting. Fra den Dag i Majmaaned, da mine Genvordigheder begyndte, kunde jeg saa tydeligt mærke en lidt efter lidt tiltagende Svaghed, jeg var ligesom bleven for mat til at styre og lede mig hvorhen jeg vilde; en Sverm af smaa Skadedyr havde trængt ind i mit Indre og udhulet mig. Hvad om Gud ligefrem os últimos meses tinham sido tão singularmente duros comigo? Eu não reconhecia mais de modo algum meu espírito lúcido, em toda parte tinha os mais estranhos aborrecimentos. Não podia me sentar afastado num banco ou mover um pouco meu pé até um lugar qualquer sem ser assaltado por pequenas e insignificantes casualidades, lamentáveis bagatelas que se infiltravam em minhas ideias e espalhavam minhas forças por todos os ventos. Um cachorro que passava depressa por mim, uma rosa amarela na botoeira de um senhor podiam colocar meus pensamentos a vibrar e me ocupavam por longo tempo. O que é que me faltava? $\mathrm{O}$ dedo do Senhor tinha apontado para mim? Mas por que justamente para mim? Por que não da mesma forma para um homem da América do Sul, nesse caso? Quando ponderava as coisas era-me [26] cada vez mais incompreensível que justamente eu devesse ser exposto como cobaia do capricho da graça de Deus. Era um modo de proceder muito peculiar saltar por cima de todo um mundo para me alcançar; ora, aí estavam tanto o vendedor de livros usados Pascha quanto o agente marítimo Hennechen.

Eu caminhava e deliberava sobre esse assunto e não conseguia me livrar dele, encontrava as mais substanciais objeções a essa arbitrariedade do Senhor de me deixar expiar a culpa de todos. Mesmo depois que tinha encontrado um banco e me sentado, essa pergunta continuava a me ocupar e me impedia de pensar em outra coisa. Desde aquele dia de maio em que tinham começado minhas contrariedades, podia perceber bem claramente uma fraqueza que crescia pouco a pouco, era como se tivesse ficado extenuado demais para me dirigir e conduzir até onde queria; um enxame de bichinhos nocivos tinha se infiltrado em meu íntimo 
havde i Sinde at Ødelægge mig ganske? Jeg rejste mig op og drev frem og tilbage foran Bænken.

Mit hele Væsen var i dette $\varnothing$ jeblik i den højeste Grad af Pine; jeg havde endog Smærter [27] i Armene og kunde knapt holde ud at bære dem paa sædvanlig Maade. Af mit sidste svære Maaltid følte jeg ogsaa et stærkt Ubehag, jeg var overmæt og ophidset og spadsered frem og tilbage, uden at se op; de Mennesker, som kom og gik omkring mig, gled mig forbi som Skimt. Endelig blev min Bænk optagen af et Par Herrer, som tændte sine Cigarer og passiared højt; jeg blev vred og vilde tiltale dem, men vendte om og gik helt over til den anden Kant af Parken, hvor jeg fandt mig en ny Bænk. Jeg satte mig.

Tanken paa Gud begyndte atter at optage mig. Jeg syntes, det var højst uforsvarligt af ham at lægge sig imellem hver Gang, jeg søgte efter en Post, og forstyrre det hele, aldenstund det blot var Mad for Dagen, jeg bad om. Jeg havde saa tydelig mærket, at naar jeg sulted lidt længe ad Gangen, var det ligesom min Hjærne randt mig ganske stille ud af Hovedet og gjorde mig tom. Mit Hoved blev let og fraværende, jeg følte ikke længer dets Tyngde paa mine Skuldre, og jeg havde en Fornemmelse af, at mine Øjne glante altfor vidtaabent, naar jeg saa paa nogen.

[28] Jeg sad der paa Bænken og tænkte over alt dette og blev mer og mer bitter mod Gud for hans vedholdende Plagerier. Hvis han mente at drage mig nærmere til sig og gøre mig bedre ved at udpine mig og lægge Modgang paa Modgang i min Vej, saa tog han lidt fejl, kunde jeg forsikkre ham. Og e me deixado oco. E se Deus simplesmente tivesse a intenção de me aniquilar por inteiro? Levantei-me e caminhei para frente e para trás diante do banco.

Todo o meu ser estava nesse instante no mais alto grau de tormento; tinha inclusive dores [27] nos braços e mal podia aguentar mantê-los da maneira habitual. Também sentia um intenso mal-estar oriundo de minha última refeição consistente, estava saciado e agitado e passeava de um lado para o outro sem erguer os olhos; as pessoas que iam e vinham ao meu redor deslizavam por mim como vislumbres. Por fim, meu banco foi ocupado por alguns senhores que acenderam seus charutos e tagarelavam alto; fiquei furioso e quis dirigir-lhes a palavra, mas dei meia-volta e atravessei todo o parque até o outro lado, onde encontrei um novo banco para mim. Sentei-me.

O pensamento acerca de Deus começou novamente a ocupar-me. Parecia-me altamente irresponsável de sua parte intervir cada vez que eu procurava um emprego e atrapalhar tudo, já que eu só estava pedindo o pão de cada dia. Eu tinha percebido com bastante clareza que quando passava fome por algum tempo era como se meu cérebro escorresse de mansinho inteiramente para fora da cabeça e me deixasse vazio. Minha cabeça ficava leve e ausente, eu não sentia mais seu peso sobre meus ombros e tinha uma sensação de que meus olhos se fixavam esbugalhados em demasia quando eu olhava para alguma coisa.

[28] Estava ali sentado no banco, pensando sobre tudo isso, e fiquei cada vez mais amargurado em relação a Deus por seus contínuos tormentos. Se pretendia puxar-me para mais perto de si e tornar-me melhor exaurindo-me e colocando adversidade sobre adversidade em meu caminho, então 
jeg saa op mod det høje næsten grædende af Trods og sagde ham dette en Gang for alle i mit stille Sind.

Stumper af min Børnelærdom randt mig ihu, Bibelens Stiltone sang for mine Øren, og jeg talte ganske sagte med mig selv og ladge Hovedet spydigt paa Siden. Hvi bekymred jeg mig for, hvad jeg skulde æde, hvad jeg skulde drikke, og hvad jeg skulde iføre den usle Maddiksæk kaldet mit jordiske Legem? Havde ikke min himmelske Fader sørget for mig, som for Spurvene under Himlen, og vist mig den Naade at pege paa sin ringe Tjener? Gud havde stukket sin Finger ned i mit Nervenet og lempeligt, ganske løseligt bragt lidt Uorden i Traadene. Og Gud havde trukket sin Finger tilbage, og der var Trevler og fine Rodtraade paa Fingeren af mine Nervers Traade. Og der var et aabent [29] Hul efter hans Finger, som var Guds Finger, og Saar i min Hjærne efter hans Fingers Veje. Men der Gud havde berørt mig med sin Haands Finger, lod han mig være og berørte mig ikke mer og lod mig intet ondt vederfares. Men han lod mig gaa med Fred, og han lod mig gaa med det aabne Hul. Og intet ondt vederfores mig af Gud, som er Herren i al Evighed .... .

Stød af Musik bares af Vinden op til mig fra Studenterlunden, Klokken var altsaa over to. Jeg tog mine Papirsager frem, forat forsøge at skrive noget, i det samme faldt min Barberbog ud af Lommen. Jeg aabned den og talte Bladene, der var seks Billetter tilbage. Gudskelov! sagde jeg uvilkaarlig; jeg kunde endnu blive barberet i nogle Uger og se lidt godt ud! Og jeg kom straks i en bedre Sindsstemning ved denne lille Ejendom, estava um pouco enganado, eu podia lhe garantir. E olhei para cima, rumo às alturas, quase chorando, e lhe disse isso de uma vez por todas em meu espírito silencioso.

Fragmentos do que aprendi quando criança vieram-me à memória, o tom do estilo bíblico cantou em meus ouvidos e falei bem baixinho comigo mesmo e coloquei a cabeça zombeteiramente de lado. Por que me preocupava com o que deveria comer, com o que deveria beber e com o que deveria vestir o miserável saco de vermes chamado meu corpo terreno? Não tinha meu Pai celestial cuidado de mim como dos pardais sob o céu e me concedido a graça de apontar para seu ínfimo servo? Deus tinha metido Seu dedo em minha rede de nervos e, levemente, de maneira bem superficial, provocado um pouco de desordem nas fibras. E Deus tinha retirado Seu dedo e havia fibras e delicados filamentos de minhas fibras nervosas no dedo. E havia um [29] buraco aberto deixado por Seu dedo, que era o dedo de Deus, e feridas em meu cérebro deixadas pelo caminho de Seu dedo. Mas quando Deus me tocou com o dedo de Sua mão, deixou-me em paz e não me tocou mais e não permitiu que me acontecesse mal algum. Mas Ele me deixou ir em paz, e Ele me deixou ir com o buraco aberto. E mal algum me aconteceu da parte de Deus, que é o Senhor por toda a eternidade...

Do Bosque dos Estudantes, toques de música eram trazidos até mim pelo vento; portanto, passava das duas. Peguei meu maço de papéis a fim de tentar escrever alguma coisa e no mesmo instante minha caderneta de barbeiro caiu do bolso. Abri e contei as folhas; tinham restado seis bilhetes. Graças a Deus!, disse sem querer; ainda poderia continuar barbeado por algumas semanas e manter um pouco de boa 
som jeg endnu havde tilbage; jeg glatted Billetterne omhyggeligt ud og forvared Bogen i Lommen.

Men skrive kunde jeg ikke. Efter et Par Linjer vilde der ikke falde mig noget ind; mine Tanker vare andre Steder, og jeg kunde ikke stramme mig op til nogen bestemt An- [30] strængelse. Alle Ting indvirked paa mig og distrahered mig, alt, hvad jeg saa, gav mig nye Indtryk. Fluer og smaa Myg satte sig fast paa Papiret og forstyrred mig; jeg pusted paa dem, forat faa dem væk, blæste haardere og haardere, men uden Nytte. De smaa Bæster lægger sig bagud, gør sig tunge og stritter imod, saa deres tynde Ben bugner. De er slet ikke til at flytte af Pletten. De finder signoget at hage sigfast i, spænder Hælene mod et Komma eller en Ujæunhed i Papiret og staar uryggelig stille saalænge, til de selv finder for godt at gaa sin Vej.

En Tidlang vedblev disse smaa Udyr at beskæftige mig, og jeg ladge Benene overkors og gav mig god Tid med at iagttage dem. Med én Gang bæved en eller to høje Klarinettoner op til mig fra Lunden og gav min Tanke et nyt Stød. Mismodig over ikke at kunne gøre min Artikel istand, stak jeg igen Papirerne i Lommen og læned mig bagover paa Bænken. I dette Øjeblik er mit Hoved saa klart, at jeg kan tænke de fineste Tanker, uden at trættes. Idet jeg ligger i denne Stilling og lader Øjnene løbe nedad mit Bryst og mine Ben, lægger jeg Mærke til den sprættende Bevægelse, min Fod [31] gør, hver Gang Pulsen slaar. Jeg rejser mig halvt op og ser ned paa mine Fødder, og jeg gennemgaar i denne Stund aparência! E logo o meu estado de espírito melhorou com essa pequena propriedade que ainda me restara; e alisei os bilhetes com cuidado e guardei a caderneta no bolso.

Mas não conseguia escrever. Depois de algumas linhas não queria me ocorrer mais nada; meus pensamentos estavam em outro lugar e eu não conseguia obter ânimo para algum [30] esforço definido. Todas as coisas me influenciavam e me distraíam, tudo o que eu via me dava novas impressões. Moscas e pequenos mosquitos sentavam-se firmemente no papel e me importunavam; eu os soprava para que fossem embora, soprava cada vez mais forte, mas sem resultado. As pequenas bestas deitam-se para trás, fazem-se pesadas e resistem, de modo que suas pernas delgadas se curvam. Não há como movê-las do lugar. Elas encontram algo a que se agarrar firmemente, retesam os calcanhares contra uma vírgula ou uma irregularidade do papel e permanecem quietas de maneira inabalável por muito tempo, até que elas mesmas achem por bem seguir seu caminho.

Esses diminutos monstros continuaram me ocupando por muito tempo, e cruzei as pernas e passei um bom tempo a observá-los. Logo vibraram um ou dois toques altos de clarinete vindos até mim do bosque, dando ao meu pensamento um novo impulso. Desalentado por não conseguir fazer meu artigo, meti novamente os papéis nos bolsos e me apoiei no encosto do banco. Naquele instante minha cabeça estava tão lúcida que eu podia pensar os pensamentos mais sutis sem me cansar. Enquanto estava deitado naquela posição e deixava meu olhar correr pelo meu peito e por minhas pernas, notei o movimento de contração feito pelo meu pé [31] a cada vez que o pulso batia. Soergo-me e olho para meus pés, e naquele instante ex- 
en fantastisk og fremmed Stemning, som jeg aldrig tidligere havde følt; det gav et fint, vidunderligt Sæt gennem mine Nerver, som om der gik Ilinger af koldt Lys

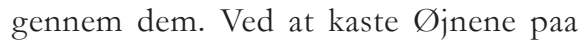
mine Sko, var det som jeg havde truffet en god Bekendt eller faaet en løsreven Part af mig selv tilbage; en Genkendelsesfølelse sittrer gennem mine Sandser, Taarerne kommer mig i Øjnene, og jeg fornemmer mine Sko som en sagte susende Tone imod mig. Svaghed! sagde jeg haardt til mig selv, og jeg knytted Hænderne og sagde Svaghed. Jeg gjorde Nar ad mig selv for disse latterlige Følelser, havde mig tilbedste med fuld Bevidsthed; jeg talte meget strængt og forstandigt, og jeg kneb Øjnene heftigt sammen, forat faa Taarerne bort. Som om jeg aldrig havde set mine Sko før, giver jeg mig til at studere deres Udseende, deres Mimik, naar jeg rørte paa Foden, deres Form og de slidte Overdele, og jeg opdager, at deres Rynker og hvide Sømme giver demUdtryk, meddeler dem Fysiognomi. Der var noget af mit eget [32] Væsen gaaet over i disse Sko, de virked paa mig som en Aande mod mit Jeg, en pustende Del af mig selv ....

Jeg sad og fabled med disse Fornemmelser en lang Stund, maaske en hel Time. En liden, gammel Mand kom og optog den anden Ende af min Bænk; idet han satte sig, pusted han tungt ud efter Gangen og sagde:

»a, ja, ja, ja, ja, ja, ja, ja, ja, ja, san!«

Saa snart jeg hørte hans Stemme, var det som en Vind fejed gennem mit Hoved, jeg lod Sko være Sko, og det forekom mig allerede, at den forvirred Sindsstemning, jeg perimento um estado de espírito fantástico e estranho, como nunca tinha sentido antes; um abalo delicado e extraordinário percorreu meus nervos, como se calafrios de luz fria os atravessassem. Ao dirigir o olhar para os meus sapatos, foi como se tivesse encontrado um velho conhecido ou conseguido reaver uma parte arrancada de mim mesmo; uma sensação de reconhecimento vibra através de meus sentidos, lágrimas vêm-me aos olhos e percebo meus sapatos como um som suave e murmurante que vem em minha direção. Fraqueza!, disse duramente a mim mesmo, e cerrei os punhos e disse "fraqueza". Zombei de mim mesmo por causa desses sentimentos ridículos, fiz troça de mim mesmo com plena consciência; falei com muita severidade e sensatez, e apertei firmemente os olhos para afastar as lágrimas. Como se nunca tivesse visto meus sapatos antes, ponho-me a estudar seu aspecto, sua mímica quando mexo o pé, sua forma e as desgastadas partes superiores, e descubro que os vincos e costuras brancas lhes conferem expressão, lhes comunicam fisionomia. Algo de minha própria [32] essência tinha passado a esses sapatos, eles agiam sobre mim como um sopro que ia de encontro a meu eu, uma parte respirante de mim mesmo...

Fiquei sentado e fabulei com essas sensações por um bocado de tempo, quase uma hora inteira. Um homem velho e pequeno veio e ocupou a outra ponta de meu banco; ao sentar-se, resfolegou pesadamente várias vezes e disse:

- Sim, sim, sim, sim, sim, sim, sim, sim, sim, sim, deveras!

Tão logo ouvi sua voz, foi como se um vento varresse pela minha cabeça; deixei os sapatos serem sapatos e já me parecia que o perplexo estado de espírito que tinha 
just havde oplevet, skrev sigfra en længst svunden Tid, kanske et Aar eller to tilbage, og var saa smaat i Færd med at udviskes af min Erindring. Jeg satte mig til at se paa den gamle.

Hvad angik han mig, denne lille Mand? Intet, ikke det ringeste! Kun at han holdt en Avis i Haanden, et gammelt Numer, med Avertissementssiden ud, hvori der syntes at ligge en eller anden Ting indpakket. Jeg blev nysgærrig og kunde ikke faa mine Øjne bort fra den Avis; jeg fik den vanvittige Idé, at det kunde være en ganske mærkelig Avis, [33] enestaaende i sit Slags; min Nysgærrighed steg, og jeg begyndte at flytte mig frem og tilbage paa Bænken. Det kunde være Dokumenter, farlige Aktstykker, stjaalet fra et Arkiv. Og der foresvæved mig noget om en hemmelig Traktat, en Sammensværgelse.

Manden sad stille og tænkte. Hvorfor bar han ikke sin Avis, som ethvert andet Menneske bar en Avis, med Titlen ud? Hvad var det for Slags Underfundigheder? Han saa ikke ud til at ville slippe sin Pakke af Haanden, ikke for alt i Verden, han turde maaske ikke engang betro den til sin egen Lomme. Jeg kunde dø paa, at der stak noget under med Pakken.

Jeg saa ud i Luften. Netop det, at det var saa umuligt at trænge ind i denne mystiske Sag, gjorde mig forstyrret af Nysgærrighed. Jeg ledte i mine Lommer efter noget at give Manden, forat komme i Samtale medham, og jeg fik fat i min Barberbog, men gæmte den igen. Pludselig fik jeg i Sinde at være yderst fræk, jeg klapped mig paa min tomme Brystlomme og sagde:

»Tør jeg byde Demen Cigaret?«

[34] Tak, Manden røgte ikke, han havde maattet høre op, forat spare sine $\varnothing_{j n e}$ experimentado há pouco datava de um tempo remoto, talvez um ou dois anos atrás, e estava pouco a pouco se apagando de minha memória. Sentei-me para olhar o velho.

Que me importava esse homenzinho? Nada, nem um pouquinho! Só que ele tinha um jornal nas mãos, um número antigo, com a página de anúncios para fora, no qual parecia estar embrulhada alguma coisa. Fiquei curioso e não consegui tirar meus olhos do jornal; ocorreu-me a louca ideia de que poderia ser um jornal bastante peculiar, [33] único em seu gênero; minha curiosidade aumentou e comecei a mexer-me para frente e para trás no banco. Poderiam ser documentos, autos perigosos roubados de um arquivo. E me ocorreu vagamente algo sobre um acordo secreto, uma conspiração.

O homem estava sentado em silêncio e pensava. Por que ele não levava seu jornal como qualquer outra pessoa leva um jornal, com a capa para fora? Que gênero de astúcias eram aquelas? Ele parecia não querer deixar seu pacote escapar das mãos por nada deste mundo, talvez não pudesse sequer confiá-lo ao próprio bolso. Eu apostaria minha vida que havia algo por trás daquele pacote.

Olhei para o nada. Justamente porque era tão impossível adentrar essa coisa misteriosa, fiquei transtornado de curiosidade. Busquei alguma coisa em meus bolsos para dar ao homem a fim de iniciar uma conversa com ele, e encontrei minha caderneta do barbeiro, mas guardei-a outra vez. De súbito, tive a ideia de ser extremamente atrevido; bati em meu bolso vazio e disse:

- Posso lhe oferecer um cigarro?

[34] Obrigado, o homem não fumava, ele precisara parar de fumar a fim de poupar 
han var næsten blind. Takker forresten saa meget!

Om det var længe siden hans $\varnothing_{j n e}$ tog Skade? Saa kunde han maaske ikke læse heller? Ikke engang Aviser?

Ikke engang Aviser, desværre!

Manden saa paa mig. De syge Øjne havde hver sin Hinde, der gav dem et glasagtigt Udseende, hans Blik blev hvidt og gjorde et modbydeligtIndtryk.

$»$ De er fremmed her?« sagde han.

Ja. - Om han ikke engang kunde læse Titlen paa den Avis, han holdt i Haanden?

Næppe. - Forresten havde han straks hørt, at jeg var fremmed; der var noget i mit Tonefald, som sagde ham det. Der skulde saa lidet til, han hørte saa godt; om Natten, naar alle sov, kunde han høre Menneskene i Sideværelset puste .... Hvad jeg vilde sige, hvor bor De henne?

En Løgn stod mig med ét fuldt færdig i Hovedet. Jeg løj ufrivilligt, uden Forsæt og uden Bagtanke, jeg svared:

\section{»Paa St. Olafs Plads Numer 2.«}

[35] Virkelig? Manden kendte hver Brosten paa St. Olafs Plads. Der var en Fontæne, nogle Gaslygter, et Par Træer, han husked det hele ... Hvad Numer bor De i?

Jeg vilde gøre en Ende paa det og rejste mig, dreven til det yderste af min fikse Idé med Avisen. Hemmeligheden skulde opklares, hvad det saa end skulde koste.

»Naar De ikke kan læse den Avis, hvorfor. . .« seus olhos, estava praticamente cego. De resto, agradeço muito!

Fazia tempo que seus olhos estavam lesados? Então ele quase não conseguia ler? Nem sequer jornais?

Nem sequer jornais, infelizmente!

O homem olhou para mim. Cada um de seus olhos doentes tinha uma membrana, o que lhes dava uma aparência vítrea, seu olhar se tornara branco e causava uma impressão repulsiva.

- O senhor é forasteiro aqui? - perguntou ele.

Sim. - Ele nem sequer conseguia ler as manchetes do jornal que segurava nas mãos?

Dificilmente. De resto, ele logo tinha ouvido que eu era forasteiro; havia algo em meu sotaque que the dizia isso. Não era preciso muito para tanto, ele ouvia muito bem; à noite, quando todos dormiam, ele podia ouvir as pessoas respirando no quarto ao lado... O que eu queria dizer é: onde o senhor mora?

De súbito, eu tinha uma mentira inteiramente pronta na cabeça. Menti involuntariamente, sem propósito e sem segundas intenções; respondi:

- Na Praça Santo Olavo, número 2.

[35] É mesmo? O homem conhecia cada paralelepípedo da Praça Santo Olavo. Havia uma fonte, alguns postes de iluminação, umas árvores, ele lembrava de tudo... Em que número o senhor mora?

$\mathrm{Eu}$ queria dar um fim naquilo e me levantei, instigado ao extremo pela minha ideia fixa com o jornal. Segredos deviam ser esclarecidos, não importava o que custasse.

- Se o senhor não pode ler o jornal, por que... 
$»$ I Numer 2, syntes jeg, De sagde?« fortsatte Manden, uden at agte paa min Uro. »jeg kendte i sin Tid alle Mennesker i Numer 2. Hvad hedder Deres Vært?«

Jeg fandt i Hast et Navn, forat blive ham kvit, laved dette Navn i Øjeblikket og slynged det ud, forat standse min Plageaand.

»Happolati,« sagde jeg.

»Happolati, ja,« nikked Manden, og han misted ikke en Stavelse i dette vanskelige Navn.

Jeg saa forbauset paa ham; han sad meget alvorlig og havde en tænksom Mine. Ikke for havde jeg udtalt dette dumme Navn, som faldt mig ind, før Manden fandt sig tilrette med det og lod til at have hørt det før. [36] Imidlertid ladge han sin Pakke fra sigpaa Bænken, og jeg følte al min Nysgærrighed dirre mig gennem Nerverne. Jeg ladge Mærke til, at der var et Par fede Pletter paa Avisen.

»Er han ikke Sjømand, Deres Vært?« spurgte Manden, og der var ikke Spor af undertrykt Ironi i hans Stemme. »Jeg synes huske, at han var Sjømand?«

„Sjømand? Om Forladelse, det maa være Broderen, De kender; dette her er nemlig J. A. Happolati, Agent.«

Jeg troed, at dette vilde gøre det af med ham; men Manden gik villigt med paa alt; om jeg havde fundet et Navn som Barabas Rosenknopsen, vilde det ikke have vakt hans Mistanke.

»Det skal være en flink Mand, har jeg hørt?« sagde han, forsøgende sig frem.

»Aa, en forslagen Mand, « svared jeg, »et dygtigt Forretningshoved, Agent for alt muligt, Tyttebær paa Kina, Fjær og Dun fra Rusland, Huder, Træmasse, Skriveblæk . ...
- No número 2, me parece que o senhor disse? - prosseguiu o homem, sem ligar para minha inquietação. - Houve um tempo em que eu conhecia todas as pessoas do número 2. Como se chama o seu senhorio?

Inventei um nome a toda pressa para me livrar dele, criei esse nome num instante e o soltei para deter meu atormentador.

- Happolati - eu disse.

- Happolati, sim - assentiu o homem, e não perdeu uma sílaba desse nome difícil.

Olhei espantado para ele; estava sentado muito sério e tinha um ar pensativo. Mal tinha pronunciado esse nome estúpido que me ocorrera e o homem já tinha se conformado com ele, parecendo já tê-lo ouvido antes. [36] Nesse meio-tempo, ele colocou seu pacote sobre o banco, e senti toda a minha curiosidade estremecer pelos meus nervos. Percebi que havia algumas manchas gordurosas no jornal.

- Ele não é marinheiro, o seu senhorio? - perguntou o homem, e não havia traço de ironia reprimida em sua voz. - Acho que recordo que ele era marinheiro.

- Marinheiro? Peço desculpas, o senhor deve conhecer o irmão; esse de quem falo é J. A. Happolati, agente.

Acreditei que isso deveria acabar com ele; mas o homem aceitava tudo de bom grado; se eu tivesse inventado um nome como Barabas Rosenknopsen, isso não teria despertado sua suspeita.

- Deve ser um homem habilidoso, segundo ouvi dizer - disse ele, procedendo com cautela.

- Ah, é um homem astuto - respondi -, uma cabeça competente para negócios, um agente para todas as coisas possíveis, arandos-vermelhos para a China, penas e 
»He-he, det var da Fan!« afbrød Oldingen i høj Grad oplivet.

Dette begyndte at blive interessant. Situationen løb af med mig, og den ene Løgn efter [37] den anden opstod i mit Hoved. Jeg satte mig igen, glemte Avisen, de mærkelige Dokumenter, blev ivrig og faldt den anden i Talen. Den lille Dværgs Godtroenhed gjorde mig dumdristig, jeg vilde lyve ham hensynsløst fuld, slaa ham storslagent af Marken og bringe ham til at tie af Forbauselse.

Om han havde hørt om den elektriske Salmebog, som Happolati havde opfundet?

Hvad, elek ....

Med elektriske Bogstaver, som kunde lyse i Mørke! Et aldeles storartet Foretagende, Millioner Kroner i Bevægelse, Støberier og Trykkerier i Arbejde, Skarer af fast lønnede Mekanikere sysselsat, jeg havde hørt sige syv hundrede Mand.

»a, er det ikke som jeg siger!« sagde Manden stille. Mer sagde han ikke; han troed hvert Ord, jeg fortalte, og faldt alligevel ikke i Staver. Dette skuffed mig en Smule, jeg havde ventet at se ham forvildet af mine Paafund.

Jeg opfandt endnu et Par desperate Løgne, drev det til Hazard, ymted om, at Happolati havde været Minister i ni Aar i Persien. De har det maaske ikke paa Anelsen, hvad det[38] vil sige at være Minister i Persien? spurgtejeg. Det var mere end Konge her, eller omtremt som Sultan, om han vidste, hvad det var. Men Happolati havde klaret det hele og aldrig staaet fast. Og jeg fortalte om Ylajali, hans Datter, en Fé, en Prinsesse, som havde tre hundrede Slavinder og laa paa et Leje af gule Roser; plumas da Rússia, peles, pasta de papel, tinta de escrever...

- He-he, ele é o Diabo! - interrompeu o velho, extremamente animado.

Aquilo começou a ficar interessante. A situação me arrastava com ela e uma mentira atrás [37] da outra surgia em minha cabeça. Voltei a me sentar, esqueci o jornal, os documentos singulares, fiquei entusiasmado e interrompi a fala do meu interlocutor. A credulidade do anãozinho me deixou atrevido, queria enchê-lo impiedosamente de mentiras, abatê-lo grandiosamente e fazê-lo calar-se de espanto.

Será que ele tinha ouvido falar do hinário elétrico que Happolati inventara?

- O quê, hinário elét...

- Com letras elétricas que podem emitir luz no escuro! Um empreendimento absolutamente magnífico, milhões de coroas em circulação, fundições e tipografias trabalhando, multidões de mecânicos empregados com salário fixo, ouvi falar de setecentos homens.

- Sim, bem como eu dizia! - disse o homem calmamente. Mais ele não disse; acreditava em cada palavra que eu dizia e, no entanto, não se impressionava. Isso me decepcionou um pouquinho, tinha esperado vê-lo confuso com as minhas invencionices.

Ainda inventei algumas mentiras desesperadas, correndo riscos, murmurei que Happolati tinha sido ministro por nove anos na Pérsia. Será que ele não tinha ideia do que [38] significava ser ministro na Pérsia?, perguntei. Era mais do que ser rei aqui, ou mais ou menos como ser um sultão, se ele sabia o que era isso. Mas Happolati tinha dado conta de tudo, e nunca se atolara em dificuldades. E falei de Ilaiáli, sua filha, uma fada, uma princesa, que tinha trezentas escravas e repousava sobre um leito de rosas 
hun var det skønneste Væsen, jeg havde set, jeg havde Gud straffe mig aldrig oplevet Magen til Syn i mit Liv!

»Saa, hun var saa vakker? «yttred den gamle med en fraværende Mine og saa ned i Marken.

Vakker? Hun var dejlig, hun var syndigt sød! Øjne som Raasilke, Arme af Rav! Bare et enkelt Blik af hende var forførende som et Kys, og naar hun kaldte paa mig, jog hendes Stemme mig som en Straale af Vin lige ind i min Sjæls Fosfor. Hvorfor skulde hun ikke være saapas dejlig? Tog han hende for et Regningsbud eller for noget i Brandvæsenet? Hun var simpelthen en Himlens Herlighed, skulde jeg sige ham, et Æventyr.

»a, ja!« sagde Manden lidt betuttet.

Hans Ro keded mig; jeg var bleven ophidset af min egen Stemme og talte i fuldt [39] Alvor. De stjaalne Arkivsager, Traktaten med en eller anden fremmed Magt, var ikke mere i min Tanke; den lille, flade Pakke laa der paa Bænken imellem os, og jeg havde ikke længer den ringeste Lyst til at undersøge den og se, hvad den indeholdt. Jeg var helt optagen af mine egne Historier, der drev underlige Syner forbi mine $\varnothing_{j n e}$ Blodet steg mig til Hovedet, og jeg løj af fuld Hals.

I dette Øjeblik syntes Manden at ville gaa. Han letted paa sig og spurgte, for ikke at bryde for brat af:

»Han skal have svære Ejendomme denne Happolati?«

Hvor turde denne blinde, modbydelige Olding tumle med det fremmede Navn, jeg havde digtet op, som om det var et almindeligt Navn og stod paa hvert Høkerskildt i amarelas; ela era a mais bela criatura que eu tinha visto, que Deus me castigue se em minha vida já contemplei algo semelhante!

- Então ela era tão formosa?-observou o velho com um ar ausente, olhando para o chão.

Formosa? Ela era magnífica, ela era pecaminosamente encantadora! Olhos como seda crua, braços de âmbar! Um único de seus olhares era sedutor como um beijo, e quando ela chamava por mim, sua voz ia como um jorro de vinho direto ao fósforo de minha alma. Por que ela não poderia ser tão magnífica?Será que ele a tomava por uma cobradora ou por alguém do corpo de bombeiros? Ela era simplesmente uma glória dos céus, isso eu tinha de lhe dizer, uma aventura.

- Sim, sim! - disse o homem, um pouco perplexo.

Sua calma me aborrecia; eu ficara agitado com a minha própria voz e falava com toda [39] seriedade. Os arquivos roubados, o tratado com uma ou outra potência estrangeira não estavam mais em meu pensamento; o pacote pequeno e achatado jazia entre nós sobre o banco, e eu não tinha mais a menor vontade de examiná-lo e ver o que continha. Estava inteiramente ocupado com minhas próprias histórias, estranhas imagens passavam diante de meus olhos, o sangue me subia à cabeça e eu mentia a plenos pulmões.

Nesse momento, pareceu que o homem queria ir embora. Ele se levantou e perguntou, para não interromper tão bruscamente:

- Ele deve ter propriedades imensas, esse Happolati?

Como aquele velhote cego e repugnante se atrevia a brincar com o nome desconhecido que eu inventara como se fosse um nome ordinário e estivesse em cada tabuleta 
Byen? Han snubled aldrig paa et Bogstav og glemte ikke en Stavelse; dette Navn havde bidt sig fast $\mathrm{i}$ hans Hjærne og slaaet Rødder i samme Stund. Jeg blev ærgerlig, en indre Forbittrelse begyndte at opstaa i mig mod dette Menneske, som intet kunde bringe i Knibe og intet gøre mistænksom.

[40] »Det kender jeg ikke til,« svared jeg derfor tvært; »jeg kender aldeles ikke til det. Lad mig forresten sige Dem nu en Gang for alle, at han hedder Johan Arendt Happolati, at dømme efter hans egne Forbogstaver.«

»ohan Arendt Happolati«, gentog Manden lidt forundret over min Heftighed. Saa taug han.

»De skulde set hans Kone, " sagde jeg rasende; »tykkere Menneske... . Ja, De tror kanske ikke, at hun var videre tyk?«

Jo, det syntes han nok, han ikke kunde fragaa; en saadan Mand havde maaske en lidt tyk Kone.

Oldingen svared sagtmodig og stille paa hvert af mine Udfald og søgte efter Ord, som om han var bange for at forgaa sig og gøre mig vred.

$»$ Helvedes Pine, Mand, tror De maaske, at jeg sidder her og lyver Dem kapitalt fuld?« raabte jeg ude af mig selv. »Tror De kanske ikke engang, at der gives en Mand ved Navn Happolati? Jeg har aldrig set paa Magen til Trods og Ondskab hos en gammel Mand! Hvad Fan gaar der af Dem? De har kanske ovenikøbet tænkt ved Dem selv, at jeg var en yderlig fattig Mand, som sad her i min [41] bedste Puds, uden et Etui fuldt af Cigaretter i Lommen? En saadan Behandling, som Deres, er jeg ikke vant til, skal jeg sige Dem, og jeg taaler den Gud døde mig ikke, hverken af Dem eller nogen anden, saa meget De ved det!« de mercearia da cidade? Ele jamais tropeçara numa letra nem esquecera uma sílaba; esse nome tinha cravado os dentes em seu cérebro e fincado raízes instantaneamente. Fiquei irritado, um despeito surdo começou a nascer em mim contra esse homem, a quem nada podia embaraçar nem causar desconfiança.

[40] - Nada sei a respeito - respondi, por isso, aborrecido -, absolutamente nada. Aliás, deixe-me dizer-lhe agora de uma vez por todas que ele se chama Johan Arendt Happolati, a julgar por suas próprias iniciais.

- Johan Arendt Happolati - repetiu o homem, um pouco surpreso com a minha veemência. E então se calou.

- O senhor devia ver sua mulher - respondi enfurecido; - a mais gorda das criaturas... Sim, o senhor talvez não acredite que ela seja tão gorda?

Sim, como não, era o que lhe parecia, ele não podia negar; um homem desses possivelmente tem uma mulherzinha gorda.

$\mathrm{O}$ velho respondeu suave e calmamente a cada um dos meus ataques, escolhendo as palavras, como se tivesse receio de cometer um erro e me enfurecer.

- Pelos tormentos do inferno, homem, será que o senhor talvez pensa que me sento aqui e o encho de mentiras? - gritei fora de mim. - Será que o senhor talvez nem sequer acredita que exista um homem chamado Happolati? Nunca vi tamanha teimosia e maldade num velho! Que diabo se passa com o senhor? Será que ainda por cima o senhor talvez pensou lá consigo mesmo que eu era um homem extremamente pobre, que estou aqui sentado com a minha [41] melhor roupa sem ter um estojo cheio de cigarros no bolso? Devo dizer-lhe que não estou acostumado a receber um tratamento como esse do senhor, e não o 
Manden havde rejst sig. Med gabende Mund stod han stum og hørte paa mit Udbrud indtil det var tilende, saa greb han hurtigt sin Pakke paa Bænken og gik, næsten løb henad Gangen med smaa Oldingeskridt.

Jeg sad tilbage og saa paa hans Ryg, som gled mer og mer bort og syntes at lude mer og mer sammen. Jeg ved ikke, hvor jeg fik det Indtryk fra, men det forekom mig, at jeg aldrig havde set en uærligere, lastefuldere Ryg end denne, og jeg angred ikke, at jeg havde skældt Mennesket ud, før han forlod $\operatorname{mig}$....

Dagen begyndte at hælde. Solen sank, det tog paa at suse lidt i Træerne omkring, og Barnepigerne, som sad i Klynger henne ved Balancerstangen, belaved sigpaa at trille sine Vogne hjem. Jeg var rolig og vel tilmode. Den Ophidselse, jeg just havde været i, ladge sig lidt efter hvert, jeg faldt sammen, [42] blev slap og begyndte at føle mig søvnig; den store Mængde Brød, jeg havde spist, var mig heller ikke længer til synderlig Mén. I den bedste Stemning læned jeg mig bagover paa Bænken, lukked Øjnene og blev mer og mer døsig, jeg blunded og var lige ved at falde i fast Søvn, da en Parkmand ladge sin Haand paa min Skulder og sagde:

\section{»De maa ikke sidde og sove herinde.«}

»Nej,« sagde jeg og rejste mig straks. Og med ét Slag stod atter min sørgelige Stilling lyslevende for mine $\varnothing_{\text {jne. Jeg maatte gøre }}$ noget, finde paa et eller andet! At søge Pladse havde ikke nyttet mig; de Anbefalinger, jeg gik og viste frem, var blevet lidt gamle tolero, que Deus me mate se o fizer, nem do senhor nem de outra pessoa, fique o senhor sabendo!

O homem tinha se levantado. Boquiaberto, ele ficou parado, mudo e ouviu meu rompante até o fim, então pegou rapidamente seu pacote do banco e se foi, quase correndo ao longo da calçada com pequenos passos de velho.

Reclinei-me e olhei suas costas, que se afastavam mais e mais e pareciam curvar-se mais e mais. Eu não sabia de onde me vinha essa impressão, mas me parecia que nunca tinha visto costas mais desonestas e mais viciosas que essas, e não me arrependi por haver censurado o homem antes de ele me deixar...

$\mathrm{O}$ dia começou a declinar. $\mathrm{O}$ sol baixou, as árvores em volta começaram a farfalhar um pouco, e as babás, que estavam sentadas em grupos junto ao balanço, prepararam-se para empurrar seus carrinhos para casa. Eu estava tranquilo e me sentia bem. A agitação em que eu ainda agora estivera amainou pouco a pouco, sucumbi, [42] fiquei lânguido e começei a me sentir sonolento; a grande quantidade de pão que eu tinha comido tampouco ainda me causava algum dano especial. No melhor dos humores, reclinei-me no banco, fechei os olhos e fiquei cada vez mais modorrento; cochilei e estava prestes a cair em sono profundo quando um guarda do parque colocou a mão sobre meu ombro e disse:

- Não é permitido sentar e dormir aqui dentro.

- Não - eu disse, e me levantei de imediato. E, de um golpe, a minha situação lamentável estava outra vez vividamente diante de meus olhos. Eu precisava fazer algo, inventar alguma coisa! De nada me adiantara procurar emprego; as recomendações 
og skrev sig fra altfor ukendte Personer til at kunne virke kraftigt; desuden havde disse stadige Afslag udefter Sommeren gjort mig noget forknyt. Naa - under alle Omstændigheder var min Husleje forfalden, og jeg maatte gøre en Udvej til den. Saa fik det bero med det øvrige saalænge.

Ganske uvilkaarligt havde jeg igen faaet Blyant og Papir i Hænderne, og jeg sad og skrev mekanisk Aarstallet 1848 i alle Hjørner. Om nu blot en enkelt brusende Tanke vilde [43] betage mig vældigt og lægge mig Ordene i Munden! Det havde jo hændt før, det havde virkelig hændt, at saadanne Stunder var kommet over mig, da jeg kunde Skrive et langt Stykke uden Anstrængelse og faa det velsignet godt til.

Jeg sidder der paa Bænken og skriver Snese Gange 1848, skriver dette Tal paakryds og tvers i alle mulige Façoner, og venter paa, at en brugbar Idé skal falde mig ind. En Sverm af løse Tanker flagrer om i mit Hoved, Stemningen i den hældende Dag gør mig mismodig og sentimental. Høsten er kommet og har allerede begyndt at lægge alting i Dvale, Fluer og Smaadyr har faaet det første Knæk, oppe i Træerne og nede paa Marken høres Lyden af det stridende Liv, puslende, susende uroligt, arbejdende for ikke at forgaa. Alle Krybverdenens nedtrampede Tilværelser rører sig endnu engang, stikker sine gule Hoveder op af Mosen, løfter sine Ben, føler sig frem med lange Traade og synker saa pludselig sammen, vælter om og vender Bugen ivejret. Hver Vækst har faaet sit Særpræg, et fint henaandende Pust af den første Kulde; Straaene stritter blege op mod Solen, og que eu andara apresentando tinham ficado um tanto velhas e provinham de pessoas demasiadamente desconhecidas para que pudessem ter um efeito substancial; além disso, essa constante recusa verão afora tinha me deixado um tanto desalentado. Ora - de qualquer modo, meu aluguel estava vencido e eu precisava achar uma saída para isso. Sendo assim, o resto podia ser adiado por enquanto.

Inteiramente sem querer, tinha apanhado outra vez lápis e papel, e, sentado, escrevi de modo mecânico o ano 1848 por todos os cantos. Se apenas um único pensamento vibrante [43] me arrebatasse com força e colocasse palavras em minha boca! Isso sem dúvida já acontecera antes, realmente acontecera que me sobreviessem tais momentos em que pude escrever um longo trecho sem esforço e eu o recebesse como uma benção.

Estou sentado no banco e escrevo 1848 dúzias de vezes, escrevo esse número de ponta a ponta de todas as maneiras possíveis, esperando que me ocorra uma ideia aproveitável. Um enxame de pensamentos soltos esvoaça pela minha cabeça, a atmosfera do dia declinante me deixa abatido e sentimental. O outono tinha chegado e já começara a colocar tudo para hibernar, moscas e pequenos bichos tinham recebido o primeiro golpe, no alto das árvores e junto ao chão ouvem-se ruídos da vida que luta, inquietamente farfalhante, murmurante, trabalhando para não perecer. Todas as existências espezinhadas do mundo dos insetos se mexem mais uma vez, esticam as cabeças amarelas acima do musgo, erguem as pernas, tateiam com longos filamentos e então sucumbem subitamente, tombam e viram de barriga para cima. Cada planta adquiriu seu tom característico, um sutil 
det af- [44] faldne Løv hvisler henad Jorden med en Lyd som af vandrende Silkeorme. Det er Høstens Tid, midt i Forgængelsens Karneval; Roserne har faaet Betændelse i Rødmen, et hektisk, vidunderligt Skær over den blodrøde Farve.

Jeg følte mig selv som et Kryb i Undergang, greben af Ødelæggelsen midt i denne dvalefærdige Alverden. Jeg rejste mig op, besat af sære Rædsler, og tog nogle voldsomme Skridt henad Gangen. Nej! Raabte jeg og knytted begge mine Hænder, dette maa der blive en Ende paa! Og jeg satte mig igen, tog atter Blyanten i Haanden og vilde gøre Alvor af det med en Artikel. Det kunde aldeles ikke nytte at give sig over, naar man stod med en ubetalt Husleje lige for Tænderne.

Langsomt, ganske langsomt begyndte mine Tanker at samle sig. Jeg passed paa og skrev sagte og vel overvejet et Par Sider som en Indledning til noget; det kunde være Begyndelsen til hvadsomhelst, en Rejseskildring, en politisk Artikel, eftersom jeg selv fandt for godt. Det var en ganske fortræffelig Begyndelse til noget af hvert.

[45] Saa gav jeg mig til at søge efter et bestemt Spørgsmaal, jeg kunde behandle, en Mand, en Ting at kaste mig over, og jeg kunde ikke finde noget. Under denne frugtesløse Anstrængelse begyndte der igen at komme Uorden i mine Tanker, jeg følte, hvorledes min Hjærne formelig slog Klik, mit Hoved tømtes, tømtes, og det stod tilsidst let og uden Indhold tilbage paa mine Skuldre. Jeg fornam denne glanende Tomhed i mit Hoved med hele Legemet, jeg syntes mig selv udhulet fra øverst til nederst. e brando sopro do primeiro frio; a palha se eriça palidamente rumo ao sol e as [44] folhas caídas sibilam sobre a terra com um ruído de rastejantes bichos-da-seda. É tempo de outono, em meio ao carnaval da transitoriedade; o rubor das rosas se inflamou, conferindo-lhes um matiz febril e prodigioso sobre a cor vermelho-sangue.

Sentia-me como um inseto em decadência, apanhado pela aniquilação em meio a esse universo pronto a cair em sono hibernal. Levantei-me, tomado por um estranho pavor, e dei alguns passos impetuosos ao longo do caminho. Não!, gritei e cerrei minhas duas mãos, isso precisa acabar! E sentei-me outra vez, peguei novamente o lápis e quis levar esse artigo a sério. Não adiantaria absolutamente nada dar-se por vencido quando se está com um aluguel não pago bem à frente do nariz.

Lenta, muito lentamente meus pensamentos começaram a se organizar. Fiquei atento e escrevi, devagar e muito ponderadamente, algumas páginas de introdução a alguma coisa; poderia ser o início do que quer que seja, uma descrição de viagem, um artigo político, conforme me parecesse melhor. Era um começo absolutamente excelente para uma coisa ou outra.

[45] Assim, comecei a procurar um assunto determinado de que pudesse tratar, um homem, um objeto sobre o qual pudesse me lançar, e não consegui achar nenhum. Nesse esforço infrutífero, meus pensamentos começaram a se desordenar outra vez, senti como meu cérebro literalmente falhou, minha cabeça se esvaziou, esvaziou; por fim estava leve e sem conteúdo sobre meus ombros. Percebi esse vazio atônito em minha cabeça com todo o corpo, e pareci a mim mesmo exaurido de alto a baixo. 
»Herre, min Gud og Fader!« raabte jeg i Smærte, og jeg gentog dette Raab mange Gange i Træk, uden at sige mer.

Vinden rasled i Løvet, det trak op til Uvejr. Jeg sad endnu en Stund og stirred fortabt paa mine Papirer, ladge dem saa sammen og stak dem langsomt i Lommen. Det blev køligt, og jeg havde ingen Vest mere; jeg knapped Frakken helt op i Halsen og stak Hænderne i Lommen. Saa rejste jeg mig og gik.

Om det bare havde lykkedes mig denne Gang, denne ene Gang! To Gange havde min Værtinde spurgt mig med $\varnothing$ jnene efter [46] Betalingen, og jeg havde maattet dukke mig ned og snige mig forbi hende med en forlegen Hilsen. Jeg kunde ikke gøre det igen; næste Gang jeg mødte disse Øjne, vilde jeg opsige mit Rum og gøre ærligt Rede for mig; det kunde saa alligevel ikke vare ved i Længden paa denne Maade.

Da jeg kom til Udgangen af Parken, saa jeg igen den gamle Dværg, som jeg i mit Raseri havde jaget paa Flugt. Den mystiske Avispakke laa opslagen ved Siden af ham paa Bænken, fuld af Mad af forskellige Sorter, som han sad og bed af. Jeg vilde lige med ét gaa hen til ham og undsylde mig, bede om Tilgivelse for min Opførsel, men hans Mad stødte mig tilbage; de gamle Fingre, der saa ud som ti rynkede Klør, klemte modbydeligtom de fede Smørogbrød, jeg følte Kvalme og gik ham forbi, uden at tiltale ham. Han kendte mig ikke, hans Øjne stirred paa mig tørre som Horn, og hans Ansigt fortrak ikke en Mine.

Og jeg fortsatte min Vej.

Efter Sædvane standsed jeg ved hver udhængt Avis, som jeg passered, forat studere Bekendtgørelserne om ledige Pladse,
- Senhor, meu Deus e Pai! - gritei em minha dor, e repeti esse grito várias vezes seguidas, sem dizer mais nada.

$\mathrm{O}$ vento farfalhou nas folhas, uma tempestade se formava. Ainda fiquei sentado por um momento e olhei, perdido, para meus papéis, então os dobrei e os coloquei lentamente no bolso.Esfriou, e eu não tinha mais colete algum; abotoei o casaco inteiro até o pescoço e meti as mãos no bolso. Então me levantei e fui embora.

Quem dera que apenas essa vez, essa única vez, eu tivesse sido bem-sucedido! Por duas vezes a proprietária tinha me interrogado com os olhos sobre o [46] pagamento, e tive de me abaixar e me esquivar dela com um cumprimento constrangido. Não podia fazer aquilo de novo; a próxima vez que me deparasse com aqueles olhos, notificaria a saída de meu quarto e me explicaria honestamente; de qualquer forma, isso não poderia se prolongar daquela maneira.

Quando cheguei à saída do parque, vi outra vez o velho anão que eu afugentara em minha fúria. $\mathrm{O}$ misterioso pacote de jornais estava aberto a seu lado sobre o banco, cheio de diferentes tipos de comida, que, sentado, ele mordiscava. Quis ir imediatamente até ele e me desculpar, pedir perdão pelo meu comportamento, mas sua comida me repeliu; os dedos velhos, que pareciam dez garras encarquilhadas, apertavam asquerosamente o gorduroso pão com manteiga, senti náuseas e passei por ele sem lhe dirigir a palavra. Ele não me reconheceu, seus olhos me encararam secos como chifres e seu rosto não manifestou qualquer expressão.

E segui meu caminho.

Como de costume, fiquei parado diante de cada jornal exposto por que passei para estudar os anúncios de emprego, e [47] fui 
og jeg [47] var saa heldig at finde én, som jeg kunde paatage mig: En Købmand paa Grønlandsleret søgte efter en Mand til et ParTimers Bogførsel hver Aften; Løn efter Overenskomst. Jeg notered mig Mandens Adresse og bad i Taushed til Gud om denne Plads; jeg vilde forlange mindre end nogen anden for Arbejdet, femti Øre var rigeligt, eller kanske firti Øre; det fik blive ganske som det vilde med det.

Da jeg kom hjem, laa der paa mit Bord en Seddel fra min Værtinde, hvori hun bad mig om at betale min Husleje i Forskud eller flytte ud, saa snart jeg kunde. Jeg maatte ikke optage det fortrydeligt, det var aleneste en nødig Begæring. Venskabeligst Madam Gundersen.

Jeg skrev en Ansøgning til Købmand Christie Grønlandsleret Numer 31, ladge de i en Konvolut og bragte den ned i Kassen paa Hjørnet. Saa gik jeg op paa mit Værelse igen og satte mig til at tænke i Gyngestolen, mens Mørket blev tættere og tættere. Det begyndte at blive vanskeligt at holde sig oppe nu. bem-sucedido em encontrar um que eu poderia assumir: um comerciante da rua Grønlandsleret estava à procura de um homem para algumas horas de contabilidade por noite; salário a combinar.Anotei o endereço do homem e, em silêncio, supliquei a Deus por aquele posto; eu pediria menos que qualquer outro pelo trabalho, cinquenta øre seriam suficientes, ou talvez quarenta; as coisas ficariam como bem entendessem.

Ao chegar em casa, havia um bilhete da proprietária sobre minha mesa, no qual me pedia para pagar o aluguel adiantado ou me mudar tão logo pudesse. Eu não devia me aborrecer com isso, era tão somente uma solicitação necessária. Cordialmente, sra. Gundersen.

Escrevi uma carta de interesse ao comerciante Christie, rua Grønlandsleret, 31, coloquei-a num envelope e o levei para baixo, até a caixa da esquina. Então subi de novo a meu quarto e me sentei na cadeira de balanço para pensar enquanto a escuridão se adensava cada vez mais. Agora começava a ficar difícil manter-se em pé. 


\section{Referências bibliográficas}

\section{Obras de Knut Hamsun:}

HAMSUN, Knut. Sult. København: P. G. Philipsen, 1890.

_. La Faim, tradução de Georges Sartreau. Paris: Presses du Compagnonnage, 1969. 1971. . Fome, tradução de Carlos Drummond de Andrade. Rio de Janeiro: Opera Mundi,

\section{Dicionários consultados:}

AXELSEN, Jens. Dansk-Engelsk Ordbog. 10. ed. København: Gyldendal, 1995. (1 CD$-\mathrm{ROM})$

BORK, Egon et al. Dansk-Tysk Ordbog. 10. ed. København: Gyldendal, 1996. (1 CD$-\mathrm{ROM})$

BRÜELS, Sven et al. Fremmedordbog. 11. ed. København: Gyldendal, 1999. (1 CD-ROM)

Dicionários PRO de lingua francesa. Porto: Porto, 2005. (1 CD-ROM)

FERREIRA, Aurélio Buarque de Holanda. Novo dicionário eletrônico Aurélio. Curitiba: Positivo, 2009. (1 CD-ROM)

HOUAISS, Antônio. Dicionário eletrônico da língua portuguesa. Rio de Janeiro: Objetiva, 2006. (1 CD-ROM)

KAPER, J. Dansk-Norsk-Tysk. Haand-Ordbog. 3. ed. Kjøbenhavn: Gyldendal, 1889.

KIRKEBY, Willy A. Engelsk ordbok: Norsk-engelsk, Engelsk-norsk. Oslo: Universitetsforlaget, 1999. (1 CD-ROM)

LARSEN, A. Dansk-Norsk-Engelsk Ordbog. 3. ed. København: Gyldendal, 1897.

NILSSON, Kåre. Norsk-portugisisk ordbok. Oslo: Universitetsforlaget, 1994. 